\title{
2020 Idaho National Laboratory Water Use Report and Comprehensive Well Inventory (Revision 29)
}

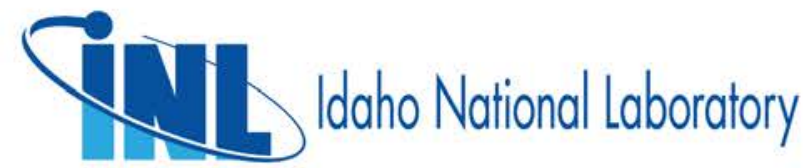



INL/EXT-21-62103

Revision 0

\title{
2020 Idaho National Laboratory Water Use Report and Comprehensive Well Inventory (Revision 29)
}

\author{
Idaho National Laboratory \\ Idaho Falls, Idaho 83415
}

http://www.inl.gov

Prepared for the U.S. Department of Energy Office of Nuclear Energy Under DOE Idaho Operations Office

Contract DE-AC07-05ID14517 
Page intentionally left blank. 


\begin{abstract}
This 2020 Idaho National Laboratory Water Use Report and Comprehensive Well Inventory (Revision 29) provides water use information for production and potable water wells at the Idaho National Laboratory (INL) Site for calendar year 2020. It also provides detailed information for new, modified, and

decommissioned wells. Two new wells (TRA-2317 and USGS-150) were drilled in 2019 and are included in this report. One well (USGS-147) was modified in 2020. The location maps and detailed construction diagrams are provided in the appendix. Fifty-six monitoring wells and boreholes were abandoned (decommissioned) in calendar year 2020. The location maps and construction diagrams, if available, for the decommissioned monitoring wells and boreholes are provided in the appendix.

This report is being submitted in accordance with the Water Rights Agreement between the State of Idaho and the United States, for the United States Department of Energy (dated 1990), the subsequent Partial Decree for Water Right 34-10901 issued June 20, 2003, and the Final Unified Decree issued August 26, 2014.
\end{abstract}


Page intentionally left blank. 


\section{CONTENTS}

ABSTRACT iii

ACRONYMS viii

1. INTRODUCTION......

2. 2020 WATER USE INFORMATION FOR THE IDAHO NATIONAL LABORATORY SITE...... 2

2.1 Water Volume for Individual Idaho National Laboratory Site Production or Potable Water Wells

2.2 Combined Total Volume Diverted from All Production and Potable Water Wells................ 6

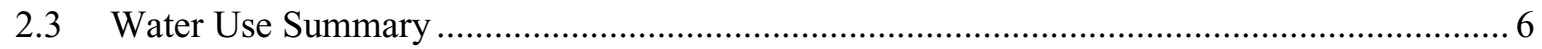

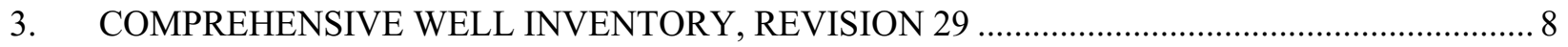

3.1 Idaho National Laboratory Site New and Modified Wells in Calendar Year 2020 ............... 8

3.2 Idaho National Laboratory Site Wells Decommissioned in Calendar Year 2020 ................. 10

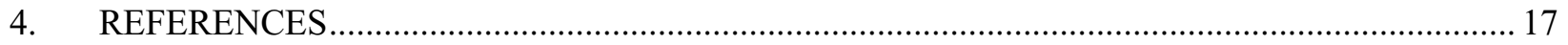

Appendix A Maps and Construction Diagrams for New Wells Completed or Modified in CY 2019 and CY 2020

Appendix B Maps and Construction Diagrams for Wells and Boreholes Decommissioned (Abandoned) in CY 2020.

\section{FIGURES}

Figure 1. Well W-05 during decommissioning activities at the RWMC .............................................. 11

Figure 2. Well D-10 after decommissioning activities were completed at the RWMC........................... 11

Figure A-1. Map showing location of newly constructed well TRA-2317 ............................................. 19

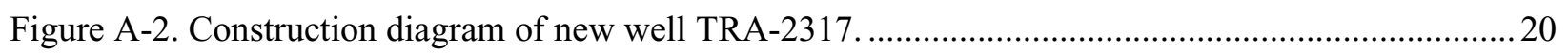

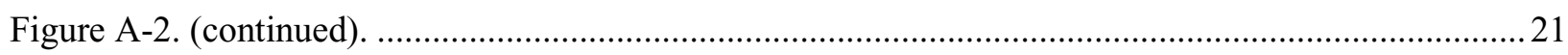

Figure A-3. Map showing location of newly constructed well USGS-150, ............................................22

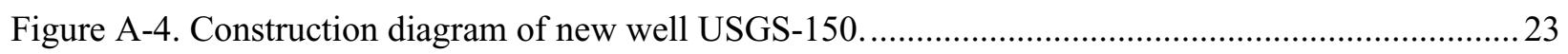

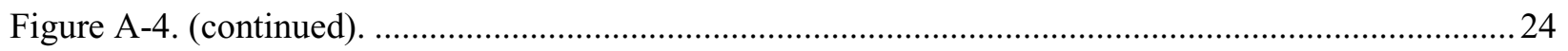

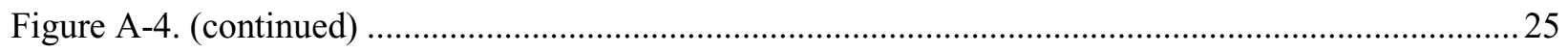

Figure A-5. Map showing location of newly modified well USGS-147 ...............................................26

Figure A-6. Construction diagram of modified well USGS-147. ........................................................2

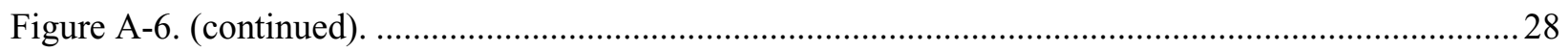

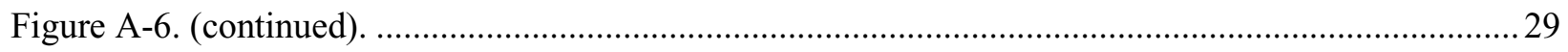

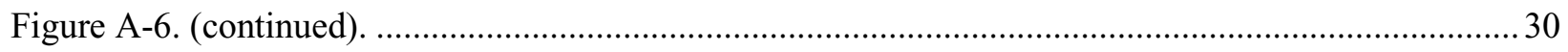

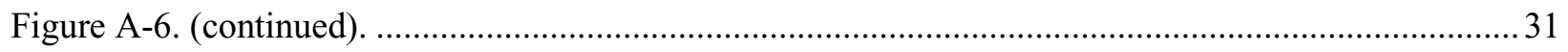


Figure B-1. Map showing location of abandoned wells and boreholes in CY 2020.............................. 33

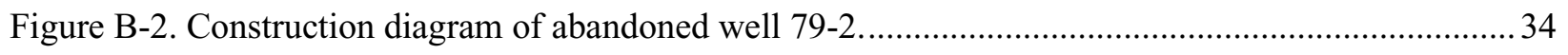

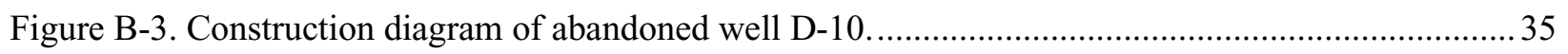

Figure B-4. Construction diagram of abandoned instrumented borehole $\mathrm{W}-13$..................................... 36

Figure B-5. Construction diagram of abandoned instrumented borehole W-23 ..................................... 37

\section{TABLES}

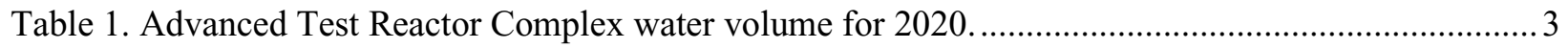

Table 2. Central Facilities Area water volume for 2020 …...................................................................... 3

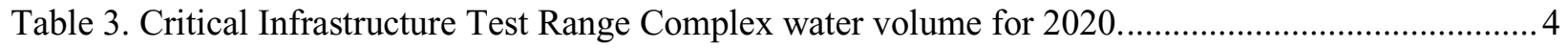

Table 4. Idaho Nuclear Technology and Engineering Center water volume for 2020 ............................. 4

Table 5. Materials and Fuels Complex water volume for 2020 ............................................................. 4

Table 6. Naval Reactors Facility water volume for 2020 ..................................................................5

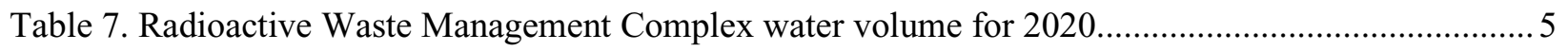

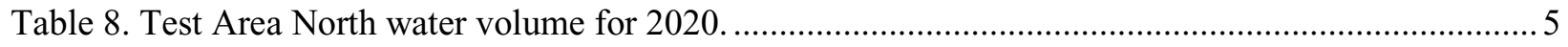

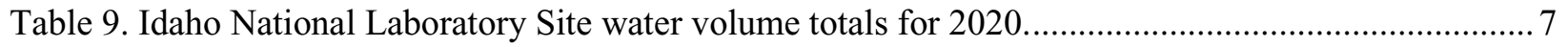

Table 10. Idaho National Laboratory Site new wells constructed in calendar year 2020 _........................9

Table 11. Idaho National Laboratory wells and boreholes decommissioned in calendar year 2020 ......... 12 
Page intentionally left blank. 


\section{ACRONYMS}

ATR Advanced Test Reactor

bbc below brass cap

bls below land surface

CERCLA Comprehensive Environmental Response, Compensation, and Liability Act

CFA Central Facilities Area

CITRC Critical Infrastructure Test Range Complex

CWI Comprehensive Well Inventory

CY calendar year

DOE U.S. Department of Energy

ESRP Eastern Snake River Plain

ESRPA Eastern Snake River Plain Aquifer

IDWR Idaho Department of Water Resources

INL Idaho National Laboratory

INTEC Idaho Nuclear Technology and Engineering Center

MFC Materials and Fuels Complex

NRF Naval Reactors Facility

RWMC Radioactive Waste Management Complex

TAN Test Area North

USGS United States Geological Surveyor, or prefix for groundwater reporting (well) common designation 
Page intentionally left blank. 


\section{Idaho National Laboratory Water Use Report and Comprehensive Well Inventory (Revision 29) \\ 1. INTRODUCTION}

This 2020 Idaho National Laboratory Water Use Report and Comprehensive Well Inventory, (Revision 29) is being submitted in accordance with the "Water Rights Agreement between the State of Idaho and the United States, for the United States Department of Energy” [1], the subsequent Partial Decree for Water Right 34-10901 [2] issued June 20, 2003, and the Final Unified Decree [3] issued August 26, 2014. As previously agreed, [8], the annual Water Use Report and Comprehensive Well Inventory are being combined and submitted as one report.

The Idaho National Laboratory (INL) Site water use reported is for calendar year (CY) 2020. Section 2 provides the annual volume of water diverted, maximum and average diversion rates, and "available" pumping levels (water depth) as required by Section 6.2.3 of the Water Rights Agreement for production and potable water wells at the INL Site. Section 2.1 provides total monthly volume, average monthly volume, total annual volume diverted, and water depths (as available) for each production or potable water well. Section 2.2 provides the total monthly volume of water diverted for each facility and the total annual volume for all INL Site production or potable water wells. Section 2.3 provides a summary of the annual water usage, including the total volume of water diverted, maximum diversion rate, and average monthly volume of water diverted for all production and potable wells.

Section 3 is the Comprehensive Well Inventory (CWI) for the INL Site as required by Section 6.2.2 of the Water Rights Agreement. Section 3.1 provides information for new and modified wells. Two new wells (TRA-2317 and USGS-150) were constructed in CY 2019 and are included in this report. One well (USGS-147) modification per IDAPA 37.03.09, "Well Construction Standards Rules," was performed in CY 2020. Section 3.2 provides information for decommissioned wells. Fifty-six wells and boreholes were decommissioned per IDAPA 37.03.09, "Well Construction Standards Rules," in CY 2020.

Appendix A provides location maps and diagrams containing detailed construction information for the two newly constructed wells and one modified well. Appendix B contains maps showing the locations of decommissioned wells and boreholes and diagrams, if available, that provide detailed construction and abandonment information. 


\section{2020 WATER USE INFORMATION FOR THE IDAHO NATIONAL LABORATORY SITE}

\subsection{Water Volume for Individual Idaho National Laboratory Site Production or Potable Water Wells}

Eight major facilities are located at the INL Site:

- Advanced Test Reactor (ATR) Complex

- Central Facilities Area (CFA)

- Critical Infrastructure Test Range Complex (CITRC)

- Idaho Nuclear Technology and Engineering Center (INTEC)

- Materials and Fuels Complex (MFC)

- Naval Reactors Facility (NRF)

- Radioactive Waste Management Complex (RWMC)

- $\quad$ Test Area North (TAN).

Each major facility is serviced by one or more production and/or potable water wells. Table 1 through Table 8 show the water information for the production or potable wells at these facilities. The total monthly volumes are recorded as close to the last day of the month as possible. Each table provides the total monthly volume, average monthly volume, and total annual volume of water diverted from each production or potable well during CY 2020. The tables provide water depth measurements where available. Many of the wells were not designed with an access line to measure the water depth. Each well is identified by its official well name, the most common alias name, and the well identification number. Footnotes are provided where applicable.

The wells identified are grouped into tables based on the INL Site facilities they provide water primarily to except for wells grouped under CFA. There are seven wells grouped under the CFA facility in Table 2. Wells CFA-1 and CFA-2 serve the actual CFA facility. The other five wells (i.e., Badging Facility Well, EBR-1, Rifle Range Well, Site-04 [Dairy Farm], and Fire Station Well) serve smaller facilities or processes.

Several wells have been removed from service and their future is being accessed. These wells (i.e., Fire Station Well, NRF-2, ANP-01, and ANP-02) continue to be listed until their use has been determined.

Section 5.3 of the Water Rights Agreement states, "The use of water for fire suppression benefits the public. Water diverted for fire suppression may be taken randomly, without a definition of the specific elements of a recordable water right, and if so, diverted for fire suppression, existing water rights shall not be diminished." The volumes in the following tables include water used for fire suppression activities. 


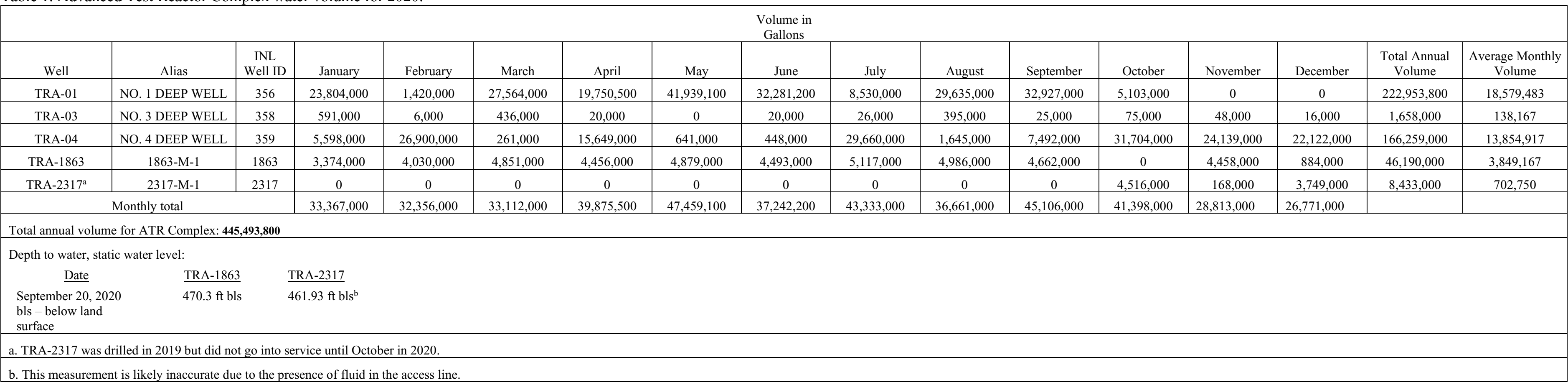

Table 2. Central Facilities Area water volume for 2020.

\begin{tabular}{|c|c|c|c|c|c|c|c|c|c|c|c|c|c|c|c|c|}
\hline \multicolumn{17}{|c|}{$\begin{array}{c}\text { Volume in } \\
\text { Gallons }\end{array}$} \\
\hline Well & Alias & $\begin{array}{c}\text { INL } \\
\text { Well ID }\end{array}$ & January & February & March & April & May & June & July & August & September & October & November & December & $\begin{array}{l}\text { Total Annual } \\
\text { Volume }\end{array}$ & $\begin{array}{l}\text { Average Monthly } \\
\text { Volume }\end{array}$ \\
\hline${\mathrm{CFA}-1^{\mathrm{a}}}$ & CFA-651 & 93 & 0 & 0 & 0 & 0 & 0 & 0 & 0 & 0 & 0 & 29,000 & 17,700 & 960,900 & $1,007,600$ & 83,967 \\
\hline CFA-2 & CFA-642 & 94 & $1,707,600$ & $1,800,000$ & $2,535,000$ & $1,481,500$ & $2,049,300$ & $5,531,800$ & $10,868,500$ & $9,698,300$ & $9,144,200$ & $1,653,100$ & $1,731,400$ & $1,001,000$ & $49,201,700$ & $4,100,142$ \\
\hline $\begin{array}{c}\text { Badging Facility } \\
\text { Well }\end{array}$ & B27-605 Main Gate & 88 & 34,460 & 1,740 & 17,210 & 3,060 & 28,490 & 46,630 & 10,480 & 7,460 & 5,920 & 3,090 & 26,980 & 32,610 & 218,130 & 18,178 \\
\hline EBR-1 & EBR 1 & 149 & 1,032 & 1,150 & 743 & 186 & 580 & 315 & 240 & 227 & 1,038 & 1,211 & 454 & 323 & 7,499 & 625 \\
\hline Rifle Range Well & B21-607 Gun Range & 267 & 3,920 & 3,010 & 1,970 & 170 & 1,470 & 1,880 & 1,490 & 1,760 & 4,270 & 1,290 & 2,110 & 1,450 & 24,790 & 2,066 \\
\hline Site-04 & B16-604 Dairy Farm & 273 & 0 & 0 & 0 & 70,995 & 101,133 & 139,970 & 144,675 & 71,620 & 67,077 & 0 & 0 & 0 & 595,470 & 49,623 \\
\hline Fire Station Well & Fire Station Well & 158 & 0 & 0 & 0 & 0 & 0 & 0 & 0 & 0 & 0 & 0 & 0 & 0 & 0 & 0 \\
\hline \multicolumn{3}{|c|}{ Monthly total } & $1,747,012$ & $1,805,900$ & $2,554,923$ & $1,555,911$ & $2,180,973$ & $5,720,595$ & $11,025,385$ & $9,779,367$ & $9,222,505$ & $1,687,691$ & $1,778,644$ & $1,996,283$ & & \\
\hline \multicolumn{17}{|c|}{ Total annual volume for CFA: $\mathbf{5 1 , 0 5 5 , 1 8 9}$} \\
\hline \multicolumn{17}{|c|}{ a. CFA-1 pump failed July 2019 and was repaired during CY 2020.} \\
\hline
\end{tabular}


Table 3. Critical Infrastructure Test Range Complex water volume for 2020.

\begin{tabular}{|c|c|c|c|c|c|c|c|c|c|c|c|c|c|c|c|c|}
\hline \multicolumn{17}{|c|}{$\begin{array}{l}\text { Volume in } \\
\text { Gallons }\end{array}$} \\
\hline Well & Alias & $\begin{array}{l}\text { INL } \\
\text { Well ID }\end{array}$ & January & February & March & April & May & June & July & August & September & October & November & December & $\begin{array}{l}\text { Total Annual } \\
\text { Volume }\end{array}$ & $\begin{array}{l}\text { Average Monthly } \\
\text { Volume }\end{array}$ \\
\hline SPERT-1 ${ }^{a}$ & PBF Deep Well No. 1 & 280 & 0 & 0 & 0 & 0 & 0 & 0 & 0 & 0 & 0 & 0 & 0 & 0 & 0 & 0 \\
\hline SPERT-2 & PBF Deep Well No. 2 & 281 & 377,900 & 350,200 & 482,600 & 318,000 & 378,500 & 361,200 & 486,400 & 357,300 & 637,500 & 342,200 & 469,000 & 545,600 & $5,106,400$ & 425,533 \\
\hline \multicolumn{3}{|c|}{ Monthly total } & 377,900 & 350,200 & 482,600 & 318,000 & 378,500 & 361,200 & 486,400 & 357,300 & 637,500 & 342,200 & 469,000 & 545,600 & & \\
\hline
\end{tabular}

Table 4. Idaho Nuclear Technology and Engineering Center water volume for 2020

\begin{tabular}{|c|c|c|c|c|c|c|c|c|c|c|c|c|c|c|c|c|}
\hline \multicolumn{17}{|c|}{$\begin{array}{c}\text { Volume in } \\
\text { Gallons }\end{array}$} \\
\hline Well & Alias & $\begin{array}{c}\text { INL } \\
\text { Well ID } \\
\end{array}$ & January & February & March & April & May & June & July & August & September & October & November & December & $\begin{array}{c}\text { Total Annual } \\
\text { Volume }\end{array}$ & \begin{tabular}{|c} 
Average Monthly \\
Volume
\end{tabular} \\
\hline CPP-01 & F-UTI- 670 & 98 & 0 & 0 & 0 & 0 & 0 & 0 & 0 & 0 & 0 & 0 & $8,405,000$ & $24,158,987$ & $32,563,987$ & $2,713,666$ \\
\hline CPP- 02 & F-UTI-671 & 99 & $16,567,000$ & $15,445,000$ & $18,803,000$ & $17,805,000$ & $19,016,000$ & $23,898,000$ & $25,099,000$ & $14,807,000$ & $20,549,000$ & $21,355,000$ & $8,235,000$ & 0 & $201,579,000$ & $16,798,250$ \\
\hline $\mathrm{CPP}-04^{\mathrm{a}}$ & P-UTI-660 & 101 & 199,055 & 198,798 & 176,876 & 81,958 & 104,645 & 191,002 & 166,997 & 195,218 & 168,074 & 239,719 & 159,439 & 182,208 & $2,063,989$ & 171,999 \\
\hline ICPP-POT-A-012a & F-UTI-699 or CPP-05 & 1186 & 199,055 & 198,798 & 176,877 & 81,957 & 104,646 & 191,002 & 166,997 & 195,217 & 168,074 & 239,719 & 159,439 & 182,208 & $2,063,989$ & 171,999 \\
\hline \multicolumn{3}{|c|}{ Monthly total } & $16,965,110$ & $15,842,596$ & $19,156,753$ & $17,968,915$ & $19,225,291$ & $24,280,004$ & $25,432,994$ & $15,197,435$ & $20,885,148$ & $21,834,438$ & $16,958,878$ & $24,523,403$ & & \\
\hline
\end{tabular}

a. One flow meter is used for potable wells CPP-04 and ICPP-POT-A-012. Operations switched between the wells weekly, so the totals are estimated to be $50 \%$ for each well.

Table 5. Materials and Fuels Complex water volume for 2020

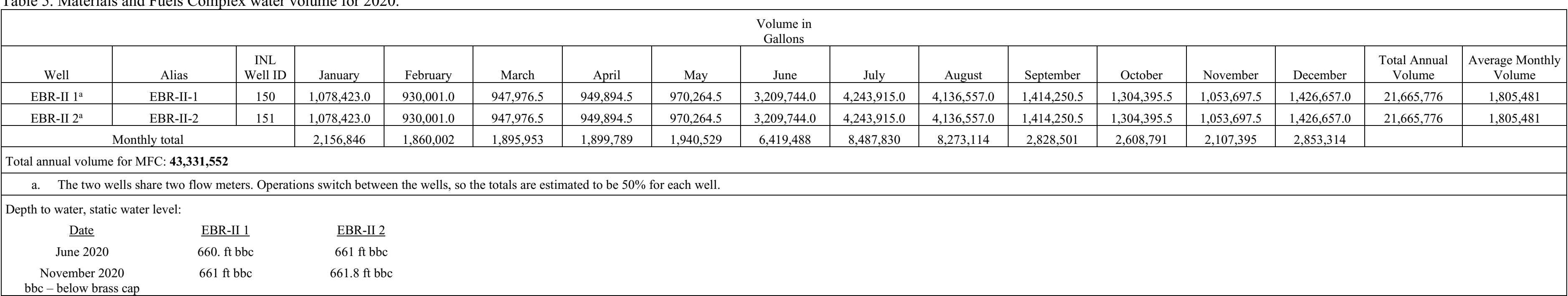




\begin{tabular}{|c|c|c|c|c|c|c|c|c|c|c|c|c|c|c|c|c|c|}
\hline \multicolumn{18}{|c|}{$\begin{array}{l}\text { Volume in } \\
\text { Gallons }\end{array}$} \\
\hline Well & & & $\begin{array}{c}\text { INL } \\
\text { Well ID }\end{array}$ & January & February & March & April & May & June & July & August & September & October & November & December & $\begin{array}{l}\text { Total Annual } \\
\text { Volume }\end{array}$ & $\begin{array}{l}\text { Average Monthly } \\
\text { Volume }\end{array}$ \\
\hline NRF-1 & & $\mathrm{F} 1$ & 240 & $1,055,195$ & 517,730 & 771,182 & 967,082 & 7 & 58,771 & 69,226 & 10,064 & 83,176 & 395,740 & 980,794 & $1,093,647$ & $6,002,614$ & 500,218 \\
\hline $\mathrm{NRF}_{-2}{ }^{\mathrm{a}}$ & & $\mathrm{F} 2$ & 241 & 0 & 0 & 0 & 0 & 0 & 0 & 0 & 0 & 0 & 0 & 0 & 0 & 0 & 0 \\
\hline NRF-3 ${ }^{b}$ & & F 3 & 242 & 105,524 & 234,553 & 205,891 & 144,612 & 134,799 & 127,870 & 129,192 & 198,722 & 137,134 & 293,059 & 368,907 & 362,025 & $2,442,288$ & 203,524 \\
\hline NRF-4 & & $\mathrm{F} 4$ & 869 & 800,247 & 537,397 & 808,115 & $1,382,292$ & $3,183,375$ & $3,258,667$ & $5,054,617$ & $6,813,924$ & $7,075,614$ & $2,036,931$ & 850,395 & $1,212,112$ & $33,013,686$ & $2,751,141$ \\
\hline NRF-1 $14^{b}$ & & & 2204 & 405,025 & 190,489 & 220,949 & 124,780 & 192,545 & 278,375 & 247,233 & 183,312 & 171,119 & 115,487 & 3,639 & 3,498 & $2,136,451$ & 178,038 \\
\hline \multicolumn{4}{|c|}{ Monthly total } & $2,365,991$ & $1,480,169$ & $2,006,137$ & $2,618,766$ & $3,510,726$ & $3,723,683$ & $5,500,268$ & $7,206,022$ & $7,467,043$ & $2,841,217$ & $2,203,735$ & $2,671,282$ & & \\
\hline \multicolumn{18}{|c|}{ Total annual volume for NRF: $\mathbf{4 3 , 5 9 5 , 0 3 9}$} \\
\hline \multicolumn{18}{|c|}{$\begin{array}{l}\text { a. NRF-2 was removed from service in } 2006 \text {. Future use will be determined. } \\
\text { b. Wells NRF-3 and NRF-14 are used as potable water wells. }\end{array}$} \\
\hline \multicolumn{18}{|c|}{ Depth to water, static water level: } \\
\hline \multicolumn{2}{|c|}{$\underline{\text { Date }}$} & \multicolumn{2}{|c|}{$\underline{\mathrm{NRF}-3}$} & \multicolumn{2}{|c|}{$\underline{N R F-14}$} & & & & & & & & & & & & \\
\hline \multirow{2}{*}{\multicolumn{2}{|c|}{$\begin{array}{c}\text { April } 2020 \\
\text { November } 2020\end{array}$}} & \multicolumn{2}{|c|}{$386.37 \mathrm{ft} \mathrm{bls}$} & \multicolumn{2}{|c|}{$385.85 \mathrm{ft} b l \mathrm{~s}$} & & & & & & & & & & & & \\
\hline \multicolumn{3}{|c|}{$\begin{array}{l}\text { November } 2020 \\
\text { bls - below land surface }\end{array}$} & & $387.07 \mathrm{f}$ & & & & & & & & & & & & & \\
\hline
\end{tabular}

Table 7. Radioactive Waste Management Complex water volume for 2020.

\begin{tabular}{|c|c|c|c|c|c|c|c|c|c|c|c|c|c|c|c|c|}
\hline \multicolumn{17}{|c|}{$\begin{array}{c}\text { Volume in } \\
\text { Gallons }\end{array}$} \\
\hline Well & Alias & $\begin{array}{c}\text { INL } \\
\text { Well ID }\end{array}$ & January & February & March & April & May & June & July & August & September & October & November & December & $\begin{array}{c}\text { Total Annual } \\
\text { Volume }\end{array}$ & $\begin{array}{c}\text { Average Monthly } \\
\text { Volume }\end{array}$ \\
\hline RWMC Production & RWMC-PROD & 268 & 569,000 & 615,000 & 840,400 & 338,100 & 318,400 & 836,700 & $1,022,000$ & $1,125,400$ & $1,173,500$ & $1,127,300$ & 860,300 & 615,000 & $9,441,100$ & 786,758 \\
\hline $\begin{array}{c}\text { PIT } 9 \text { Production } \\
\text { Well }^{a}\end{array}$ & Pit 9 Prod & 2155 & 0 & 0 & 0 & 0 & 0 & 0 & 0 & 43,000 & 0 & 0 & 0 & & 43,000 & 3,583 \\
\hline \multicolumn{3}{|c|}{ Monthly total } & 569,000 & 615,000 & 840,400 & 338,100 & 318,400 & 836,700 & $1,022,000$ & $1,168,400$ & $1,173,500$ & $1,127,300$ & 860,300 & 615,000 & & \\
\hline
\end{tabular}

a. Pit 9 Production well used as needed to provide firewater.

\begin{tabular}{|c|c|c|c|c|c|c|c|c|c|c|c|c|c|c|c|c|}
\hline \multicolumn{17}{|c|}{$\begin{array}{l}\text { Volume in } \\
\text { Gallons }\end{array}$} \\
\hline Well & Alias & $\begin{array}{c}\text { INL } \\
\text { Well ID }\end{array}$ & January & February & March & April & May & June & July & August & September & October & November & December & $\begin{array}{c}\text { Total Annual } \\
\text { Volume }\end{array}$ & \begin{tabular}{|c} 
Average Monthly \\
Volume
\end{tabular} \\
\hline ANP- $01^{a}$ & TAN-612 & 69 & 0 & 0 & 0 & 0 & 0 & 0 & 0 & 0 & 0 & 0 & 0 & 0 & 0 & 0 \\
\hline ANP- $02^{b}$ & TAN-613 & 70 & 0 & 0 & 0 & 0 & 0 & 0 & 0 & 0 & 0 & 0 & 0 & 0 & 0 & 0 \\
\hline FET-1 & TAN-632 & 154 & 0 & 236,200 & 243,700 & 257,700 & 791,700 & 35,900 & 0 & 0 & 93,600 & 307,900 & 173,200 & 260,100 & $2,400,000$ & 200,000 \\
\hline FET-2 & TAN-639 & 155 & 460,500 & 272,200 & 471,500 & 462,600 & 194,100 & 661,400 & $1,613,900$ & $1,684,600$ & $1,285,400$ & 135,600 & 255,200 & 201,200 & $7,698,200$ & 641,517 \\
\hline \multicolumn{3}{|c|}{ Monthly total } & 460,500 & 508,400 & 715,200 & 720,300 & 985,800 & 697,300 & $1,613,900$ & $1,684,600$ & $1,379,000$ & 443,500 & 428,400 & 461,300 & & \\
\hline
\end{tabular}




\subsection{Combined Total Volume Diverted from All Production and Potable Water Wells}

Table 9 provides the combined total volume from all production and potable water wells at the INL Site during CY 2020. Table 9 includes:

- Total monthly volume of water diverted for each major INL Site facility

- Combined total monthly volume diverted from all the major INL Site facilities

- Monthly average volume diverted for all wells combined

- Monthly maximum volume diverted for all wells combined

- Total annual volume diverted at the INL Site.

\subsection{Water Use Summary}

The INL Site's Federal Reserved Water Right is 35,000 acre-ft/yr. $\left(1.14 \times 10^{10} \mathrm{gal} / \mathrm{yr}\right.$. $)$, not to exceed a maximum diversion rate of $80 \mathrm{ft}^{3} / \mathrm{s}(35,906 \mathrm{gpm})$. The total volume of water diverted at the INL Site for CY 2020 was approximately $8.46 \times 10^{8}$ gal (see Table 9 ) or approximately $7.42 \%$ of the annual water right. The maximum monthly volume of water diverted was $96,901,777$ gal and the maximum diversion rate was $4.8 \mathrm{ft}^{3} / \mathrm{s}$ that occurred in July. The average monthly volume of water diverted for all INL Site production and potable wells remained within the established water right. 
Table 9. Idaho National Laboratory Site water volume totals for 2020.

\begin{tabular}{|c|c|c|c|c|c|c|c|c|c|c|c|c|}
\hline \multicolumn{13}{|c|}{$\begin{array}{l}\text { Volume in } \\
\text { Gallons }\end{array}$} \\
\hline Facility & January & February & March & April & May & June & July & August & September & October & November & December \\
\hline Advanced Test Reactor Complex & $33,367,000$ & $32,356,000$ & $33,112,000$ & $39,875,500$ & $47,459,100$ & $37,242,200$ & $43,333,000$ & $36,661,000$ & $45,106,000$ & $41,398,000$ & $28,813,000$ & $26,771,000$ \\
\hline Central Facilities Area & $1,747,012$ & $1,805,900$ & $2,554,923$ & $1,555,911$ & $2,180,973$ & $5,720,595$ & $11,025,385$ & $9,779,367$ & $9,222,505$ & $1,687,691$ & $1,778,644$ & $1,996,283$ \\
\hline $\begin{array}{l}\text { Critical Infrastructure Test Range } \\
\text { Complex }\end{array}$ & 377,900 & 350,200 & 482,600 & 318,000 & 378,500 & 361,200 & 486,400 & 357,300 & 637,500 & 342,200 & 469,000 & 545,600 \\
\hline $\begin{array}{l}\text { Idaho Nuclear Technology and } \\
\text { Engineering Center }\end{array}$ & $16,965,110$ & $15,842,596$ & $19,156,753$ & $17,968,915$ & $19,225,291$ & $24,280,004$ & $25,432,994$ & $15,197,435$ & $20,885,148$ & $21,834,438$ & $16,958,878$ & $24,523,403$ \\
\hline Materials and Fuels Complex & $2,156,846$ & $1,860,002$ & $1,895,953$ & $1,899,789$ & $1,940,529$ & $6,419,488$ & $8,487,830$ & $8,273,114$ & $2,828,501$ & $2,608,791$ & $2,107,395$ & $2,853,314$ \\
\hline Naval Reactors Facility & $2,365,991$ & $1,480,169$ & $2,006,137$ & $2,618,766$ & $3,510,726$ & $3,723,683$ & $5,500,268$ & $7,206,022$ & $7,467,043$ & $2,841,217$ & $2,203,735$ & $2,671,282$ \\
\hline Radioactive Waste Management Complex & 569,000 & 615,000 & 840,400 & 338,100 & 318,400 & 836,700 & $1,022,000$ & $1,168,400$ & $1,173,500$ & $1,127,300$ & 860,300 & 615,000 \\
\hline Test Area North & 460,500 & 508,400 & 715,200 & 720,300 & 985,800 & 697,300 & $1,613,900$ & $1,684,600$ & $1,379,000$ & 443,500 & 428,400 & 461,300 \\
\hline Monthly Totals & $58,009,359$ & $\mathbf{5 4 , 8 1 8 , 2 6 7}$ & $60,763,965$ & $65,295,282$ & $75,999,318$ & $79,281,170$ & $\mathbf{9 6 , 9 0 1 , 7 7 7}$ & $80,327,239$ & $88,699,197$ & $72,283,137$ & $53,619,352$ & $60,437,182$ \\
\hline Maximum monthly volume (gallons) & \multicolumn{3}{|c|}{$96,901,777$ (July 2020) } & & & & & & & & & \\
\hline Total average monthly volume (gallons) & \multicolumn{3}{|l|}{$70,536,270$} & & & & & & & & & \\
\hline Annual total for 2020 (gallons) & \multicolumn{3}{|l|}{$846,435,245$} & & & & & & & & & \\
\hline
\end{tabular}




\section{COMPREHENSIVE WELL INVENTORY, REVISION 29}

\subsection{Idaho National Laboratory Site New and Modified Wells in Calendar Year 2020}

One new redundant potable water well (i.e., TRA-2317) and one new seismic testing well (USGS150) were constructed at the INL Site in CY 2019 and are listed in Table 10. Construction information for both wells was received in 2020 and are included in this report. The redundant potable water well was drilled by Thomas Drilling, Inc. and the seismic testing well was drilled by the United States Geological Survey Research Drilling Program (USGS RDP). One well (USGS-147) was modified at the INL Site in CY 2020 and is listed in Table 10. USGS-147 is an aquifer monitoring well that was deepened approximately $300 \mathrm{ft}$ by the United States Geological Survey (USGS).

Well TRA-2317 was drilled in 2019 approximately 1.3 miles northwest of Monroe and Lincoln Boulevard near the ATR Complex to serve as a redundant potable water (municipal) source. This new potable water well will be used alternately with the existing well on a rotational basis. The well was drilled to a completion depth of $590 \mathrm{ft}$ bls and constructed approximately $120 \mathrm{ft}$ into the Eastern Snake River Plain Aquifer (ESRPA). Cement (approximately 4.2 cubic yards) was placed from ground surface to $52 \mathrm{ft} \mathrm{bls;} \mathrm{a} \mathrm{bentonite} \mathrm{annular} \mathrm{seal} \mathrm{was} \mathrm{then} \mathrm{used} \mathrm{from} \mathrm{ground} \mathrm{surface} \mathrm{to} \mathrm{approximately} 520 \mathrm{ft}$ bls. Carbon steel surface casing (16-in) extends from ground surface to $268 \mathrm{ft}$ bls; carbon steel well casing (10-in) extends approximately $2 \mathrm{ft}$ above ground to $520 \mathrm{ft}$ bls; the well is open (not screened) from 520 to $590 \mathrm{ft}$ bls. The well is equipped with a pitless adapter unit connecting the discharge line to the potable water system (minimum $5 \mathrm{ft}$ bls); a stainless steel (4-in) discharge line extends from approximately 5 to $504 \mathrm{ft}$ bls; pump inlet ( $40 \mathrm{hp}$ submersible) was placed near $504 \mathrm{ft}$ bls. The initial water level was measured at $469.5 \mathrm{ft}$ bls and was taken June 4, 2019. After the well development and system operability test, water-quality sampling was performed on the well. The results were "absent" for total coliforms and Escherichia coli. Information was not complete until CY 2020 and therefore is being included in this report.

Well USGS-150 was drilled in 2019 approximately 0.15 miles west of the ATR Complex. The purpose for drilling well USGS-150 was to collect geologic, geophysical, and seismic data to improve models used to understand geologic hazards near the ATR Complex. The borehole was originally proposed to be constructed as a monitoring well; however, due to continued problems surrounding borehole stability, efforts to construct the borehole for monitoring are on standby. The well was cored to a depth of 1,399.6 ft bls. Geophysical data was collected through the drill rod and within the open borehole; however, stability issues near $695 \mathrm{ft}$ bls prevented continuous logging. Open borehole logs were successfully collected in short sections using temporary casing, but not all sections could be logged. Attempts to grout and stabilize difficult sections were not successful. USGS-150 was capped after measurements were collected, but the borehole remains open until a determination is made whether to reenter the borehole and take additional measurements or whether to abandon the borehole. Paleomagnetic analyses will be run on core samples and used for interpretation of related stratigraphy. Information was not complete until CY 2020; therefore, it is being included in this report.

Well USGS-147 was originally drilled in 2018 approximately 2 miles southeast of RWMC. The purpose for the drilling and construction of well USGS-147 was to improve the understanding of hydrogeology southwest of the CFA and will also serve to fill a data gap outlined in the INL groundwater monitoring plan (DOE/ID 2012). Construction was halted at a depth of 751 and a submersible pump and measurement line were installed. The well was placed in the USGS monitoring network and water-quality data were collected between 2018 and 2020, data collected include water-quality samples and water levels.

Well USGS-147 was deepened from 751 to $1048 \mathrm{ft}$ bls in CY 2020 and constructed approximately $390 \mathrm{ft}$ into the ESRPA. The well is open (not screened) between 751 and 1,048 ft bls; the carbon steel 
well casing (6-in.) extends approximately $3.5 \mathrm{ft}$ above ground to $751 \mathrm{ft}$ bls. The borehole from 1,000 and $1,048 \mathrm{ft}$ bls was filled with drill cuttings (sluff material) and not grouted. A borehole video run after reaming reveals a blockage in well USGS-147 near $817 \mathrm{ft}$ bls. Attempts to clear the bridge were not successful, so the current well depth sits near $817 \mathrm{ft}$ bls. The USGS had planned to place perforated well casing ( 5 in.) through this bridged area; however, unforeseen circumstances resulted in delays and placing the well on temporary standby. Currently, the well is capped and used to collect water levels only.

Groundwater and geologic data collected will be used to improve INL groundwater and stratigraphic framework models. Paleomagnetic analyses will be run on core samples and used for interpretation of related stratigraphy.

Maps and detailed construction diagrams of both new wells and one modified well can be found in Appendix A. The CWI database maintains detailed well information that can be provided electronically to the state of Idaho upon request.

Table 10. Idaho National Laboratory Site new wells constructed in calendar year 2020.

\begin{tabular}{|c|c|c|c|c|c|c|c|}
\hline $\begin{array}{l}\text { Well } \\
\text { Name }\end{array}$ & Type & $\begin{array}{c}\text { Borehole } \\
\text { Depth } \\
\text { (ft bls) } \\
\end{array}$ & $\begin{array}{c}\text { Casing } \\
\text { Diameter } \\
\text { (Inner) }^{\mathrm{a}}\end{array}$ & $\begin{array}{c}\text { Construction } \\
\text { Material }\end{array}$ & Status & Location & $\begin{array}{c}\text { Driller/ } \\
\text { License } \\
\text { No. }\end{array}$ \\
\hline TRA-2317 & $\begin{array}{l}\text { Potable } \\
\text { Water }\end{array}$ & 590 & $\begin{array}{l}16-\mathrm{in} . \\
\text { from } 0 \text { to } \\
266 \mathrm{ft} \text { bls } \\
10-\mathrm{in} . \\
\text { from }-2 \text { to } \\
520 \mathrm{ft} \text { bls }\end{array}$ & $\begin{array}{l}\text { Carbon Steel } \\
\text { Carbon Steel }\end{array}$ & Active $^{\mathrm{b}}$ & $\begin{array}{c}\text { T03N- } \\
\text { R29E- } \\
\text { Sec. } 014 \\
\text { NW/SE/ } \\
\text { NE }\end{array}$ & $\begin{array}{l}\text { Thomas } \\
\text { Drilling, } \\
\text { Inc. / } \\
390\end{array}$ \\
\hline USGS-150 & $\begin{array}{l}\text { Seismic } \\
\text { Testing } \\
\text { Well }\end{array}$ & 1,399 & $\begin{array}{l}10 \text {-in. } \\
\text { from } 0 \text { to } \\
18.3 \mathrm{ft} \text { bls }\end{array}$ & Carbon Steel & Active $^{b}$ & $\begin{array}{c}\text { T03N- } \\
\text { R29E- } \\
\text { Sec. } 014 \\
\text { NE/SW/ } \\
\text { NW }\end{array}$ & $\begin{array}{l}\text { USGS } \\
\text { RDP }\end{array}$ \\
\hline USGS-147 & $\begin{array}{l}\text { Monitoring } \\
\text { Well } \\
\text { (Deepened } \\
\text { from } 751 \\
\text { to } 1,048 \mathrm{ft} \\
\text { bls) }\end{array}$ & 1,048 & $\begin{array}{l}10 \text {-in. } \\
\text { from } 0 \text { to } \\
14 \mathrm{ft} \text { bls } \\
8 \text {-in. from } \\
0 \text { to } 272 \mathrm{ft} \\
\text { bls } \\
6 \text {-in. from } \\
-3.5 \text { to } \\
751 \mathrm{ft} \text { bls }\end{array}$ & $\begin{array}{l}\text { Carbon Steel } \\
\text { Carbon Steel } \\
\text { Carbon Steel }\end{array}$ & Active & $\begin{array}{c}\text { T02N- } \\
\text { R29E- } \\
\text { Sec. 021 } \\
\text { NW/SW/ } \\
\text { SE }\end{array}$ & USGS \\
\hline
\end{tabular}

a. Negative value indicates the casing extends above the ground surface. As an example, the 10in. casing for well TRA-2317 extends $2 \mathrm{ft}$ above the ground surface to $520 \mathrm{ft}$ below land surface (bls).

b. Well drilled prior to CY 2020, detailed construction information not available until 2020 . 


\subsection{Idaho National Laboratory Site Wells Decommissioned in Calendar Year 2020}

Table 11 identifies 56 monitoring wells and monitoring boreholes that were abandoned (decommissioned). One abandonment application was submitted to the Idaho Department of Water Resources (IDWR) addressing 52 wells on June 18, 2020, for review (Reno 2020). Four additional shallow boreholes (PA-06, PA-07, PA-08, and PA-09) were not included in this decommission submittal.

Decommissioning of all 56 wells and boreholes were overseen by an Idaho Cleanup Project professional engineer, as agreed to by the IDWR (Stenzel 2009; Lewis 2020), to certify that all substantive requirements of State of Idaho Well Construction Standards Rules (IDAPA 37.03.09) were met.

Wells PA-06, PA-07, PA-08, and PA-09 were neutron access tube (NAT) boreholes that had not been used in many years and were not included in any required monitoring programs. During a demolition project for Operable Unit (OU) 7-13/14 to prepare for construction of an evapotranspiration surface barrier (DOE-ID 2019), the boreholes were exhumed. All four NAT boreholes; the 2-in.-diameter casing was removed to approximately 8 in. below ground surface, the remaining casing depth filled to the top of the casing with bentonite pellets, hydrated with water, and then covered with native fill material to grade.

Decommissioning work for the remaining 52 wells and boreholes began on July 27, 2020 and was completed on November 10, 2020. The casing was removed or cut off below grade. Instruments were removed if possible, or the wiring was cut off below grade. The remaining casing was filled with bentonite pellets to within 8 in. of ground surface and soaked with water (see Figure 1), then covered with native soil. Protective posts, if present, were removed and the remaining holes were also filled in with native soil (see Figure 2).

Appendix B contains maps showing the location of each well and borehole that was decommissioned in CY 2020. Also included in Appendix B are diagrams, if available, that provide detailed construction and decommissioning information for the wells and holes. The CWI database maintains detailed well information that can be provided electronically to the state of Idaho upon request. 


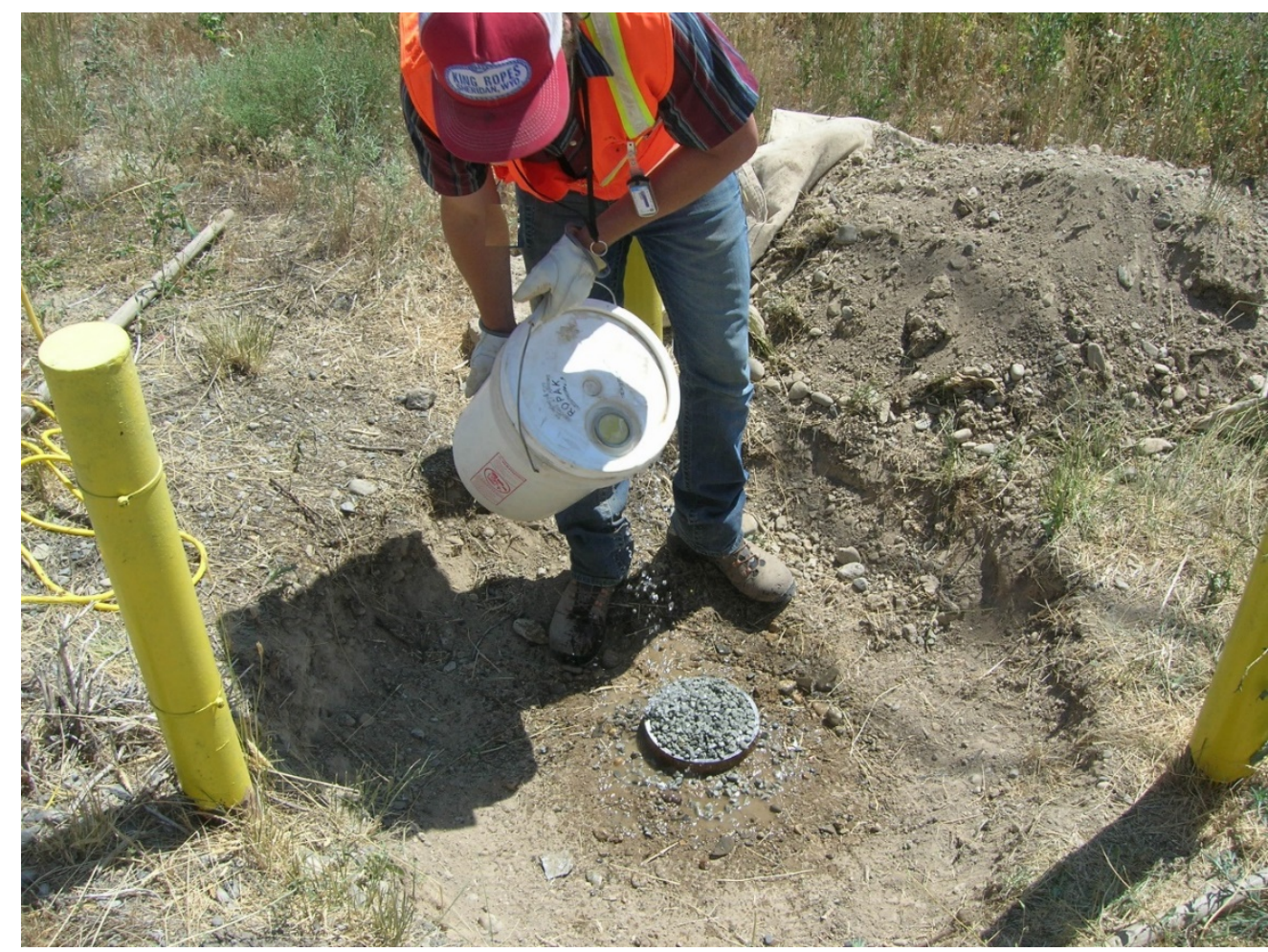

Figure 1. Well W-05 during decommissioning activities at the RWMC.

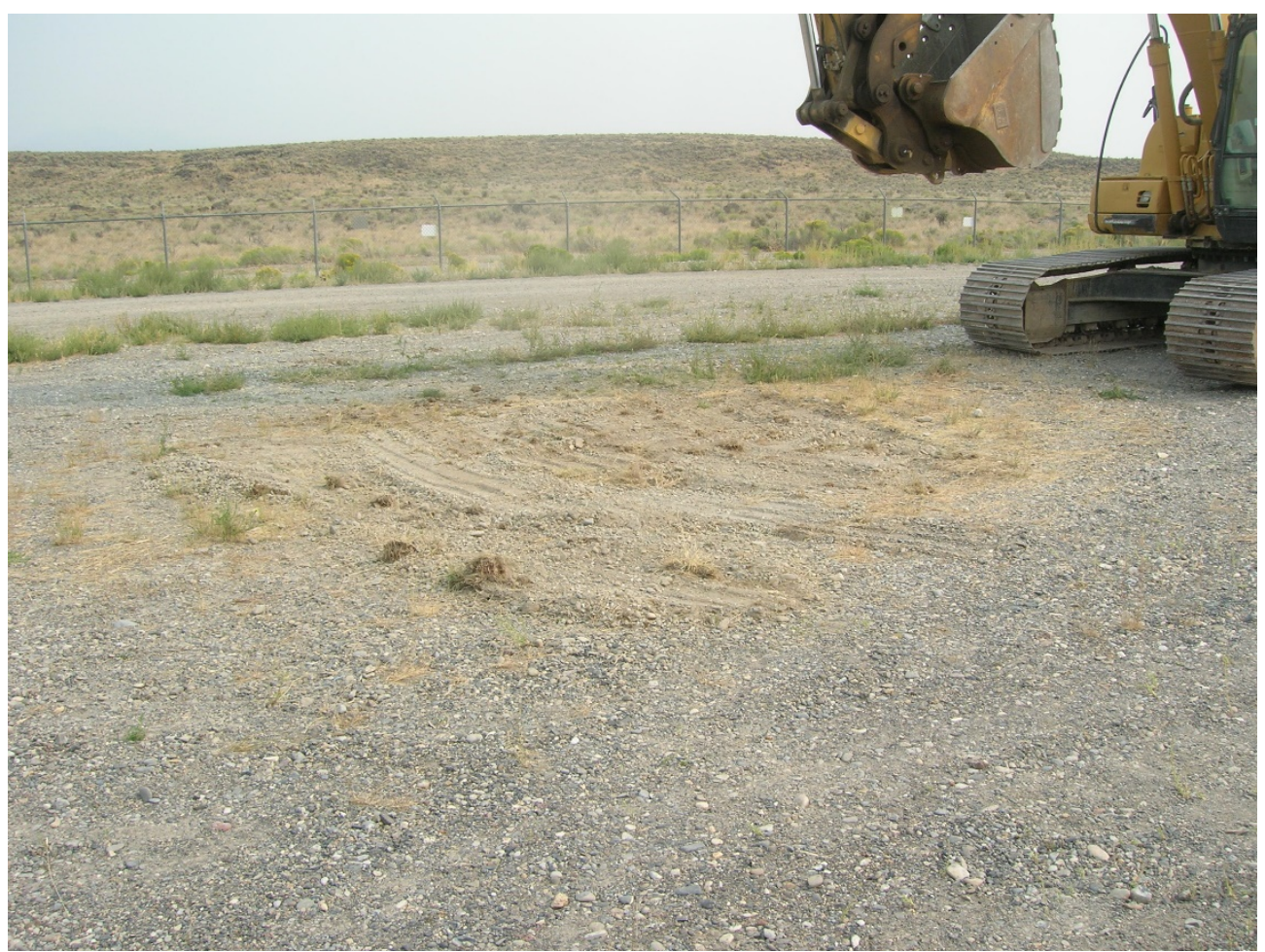

Figure 2. Well D-10 after decommissioning activities were completed at the RWMC. 
Table 11. Idaho National Laboratory wells and boreholes decommissioned in calendar year 2020.

\begin{tabular}{|c|c|c|c|c|}
\hline Well Name & Well ID & Well Type & Status & Method and Date Decommissioned \\
\hline $79-2$ & 19 & MONITORING & Abandoned & $\begin{array}{l}\text { Removed 52-ft of } 11 / 4 \text {-in. galvanized pipe, (2) } 5 \text {-ft packers, } 7 \text {-ft of vapor line, } \\
\text { cut 6-in. diameter casing approximately } 8 \text {-in. below surface, fill casing with } \\
\text { bentonite, hydrate, cover with native fill on November } 10,2020 \text {. }\end{array}$ \\
\hline $98-1$ & 1787 & $\begin{array}{c}\text { SCIENTIFIC } \\
\text { INSTRUMENTATION }\end{array}$ & Abandoned & $\begin{array}{l}\text { Cut 6-in. diameter casing approximately } 8 \text {-in. below surface, cut and cap two } \\
\text { lysimeter lines and one level logger, fill casing with bentonite, hydrate with } \\
\text { water, cover with native fill on August } 5,2020 \text {. }\end{array}$ \\
\hline $98-2$ & 1788 & $\begin{array}{c}\text { SCIENTIFIC } \\
\text { INSTRUMENTATION }\end{array}$ & Abandoned & $\begin{array}{l}\text { Cut } 8 \text {-in. diameter casing approximately } 8 \text {-in. below surface, cut and cap one } \\
\text { lysimeter lines and one vapor port, fill casing with bentonite, hydrate with water, } \\
\text { cover with native fill on August } 10,2020 \text {. }\end{array}$ \\
\hline $98-5$ & 1791 & $\begin{array}{c}\text { SCIENTIFIC } \\
\text { INSTRUMENTATION }\end{array}$ & Abandoned & $\begin{array}{l}\text { Cut 6-in. diameter casing approximately } 8 \text {-in. below surface, cut and cap two } \\
\text { lysimeter lines, fill casing with bentonite, hydrate with water, cover with native } \\
\text { fill on August } 13,2020 \text {. }\end{array}$ \\
\hline D-10 & 145 & MONITORING & Abandoned & $\begin{array}{l}\text { Cut } 6 \text {-in. diameter casing approximately } 10 \text {-in. below surface, cut one } \\
\text { tensiometer line and cover end, fill casing with bentonite, hydrate with water, } \\
\text { cover with native fill on August } 19,2020 \text {. }\end{array}$ \\
\hline MS-02 & 2134 & NOT FOUND & Abandoned & $\begin{array}{l}\text { Cut } 2 \text {-in. diameter casing approximately } 6 \text {-in. below surface, cut and cap one } \\
\text { level logger, fill casing with bentonite, hydrate with water, cover with native fill } \\
\text { on August } 5,2020 \text {. }\end{array}$ \\
\hline MS-03 & 2135 & NOT FOUND & Abandoned & $\begin{array}{l}\text { Cut } 2 \text {-in. diameter casing approximately } 6 \text {-in. below surface, cut and cap one } \\
\text { level logger, fill casing with bentonite, hydrate with water, cover with native fill } \\
\text { on August } 5,2020 \text {. }\end{array}$ \\
\hline NAT-22 & 1942 & NEUTRON ACCESS & Abandoned & $\begin{array}{l}\text { Cut } 2 \text {-in. diameter casing approximately } 6 \text {-in. below surface, fill casing with } \\
\text { bentonite, hydrate with water, cover with native fill on August } 5,2020 \text {. }\end{array}$ \\
\hline PA-01 & 251 & $\begin{array}{c}\text { SCIENTIFIC } \\
\text { INSTRUMENTATION }\end{array}$ & Abandoned & $\begin{array}{l}\text { Cut } 8 \text {-in. diameter casing approximately } 6 \text {-in. below surface, cut and cap one } \\
\text { lysimeter and one vapor port line, fill casing with bentonite, hydrate with water, } \\
\text { cover with native fill on August } 19,2020 \text {. }\end{array}$ \\
\hline PA-02 & 252 & $\begin{array}{c}\text { SCIENTIFIC } \\
\text { INSTRUMENTATION }\end{array}$ & Abandoned & $\begin{array}{l}\text { Cut } 8 \text {-in. diameter casing approximately } 6 \text {-in. below surface, cut and cap two } \\
\text { lysimeter lines, fill casing with bentonite, hydrate with water, cover with native } \\
\text { fill on August } 19,2020 \text {. }\end{array}$ \\
\hline PA-03 & 1792 & $\begin{array}{c}\text { SCIENTIFIC } \\
\text { INSTRUMENTATION }\end{array}$ & Abandoned & $\begin{array}{l}\text { Cut } 8 \text {-in. diameter casing approximately } 6 \text {-in. below surface, cut and cap one } \\
\text { lysimeter line, fill casing with bentonite, hydrate with water, cover with native } \\
\text { fill on August } 19,2020 \text {. }\end{array}$ \\
\hline PA-04 & 1793 & $\begin{array}{c}\text { SCIENTIFIC } \\
\text { INSTRUMENTATION }\end{array}$ & Abandoned & $\begin{array}{l}\text { Cut } 8 \text {-in. diameter casing approximately } 6 \text {-in. below surface, cut and cap two } \\
\text { lysimeter lines, fill casing with bentonite, hydrate with water, cover with native } \\
\text { fill on August } 27,2020 \text {. }\end{array}$ \\
\hline
\end{tabular}


Table 11. Idaho National Laboratory wells and boreholes decommissioned in calendar year 2020 (cont.)

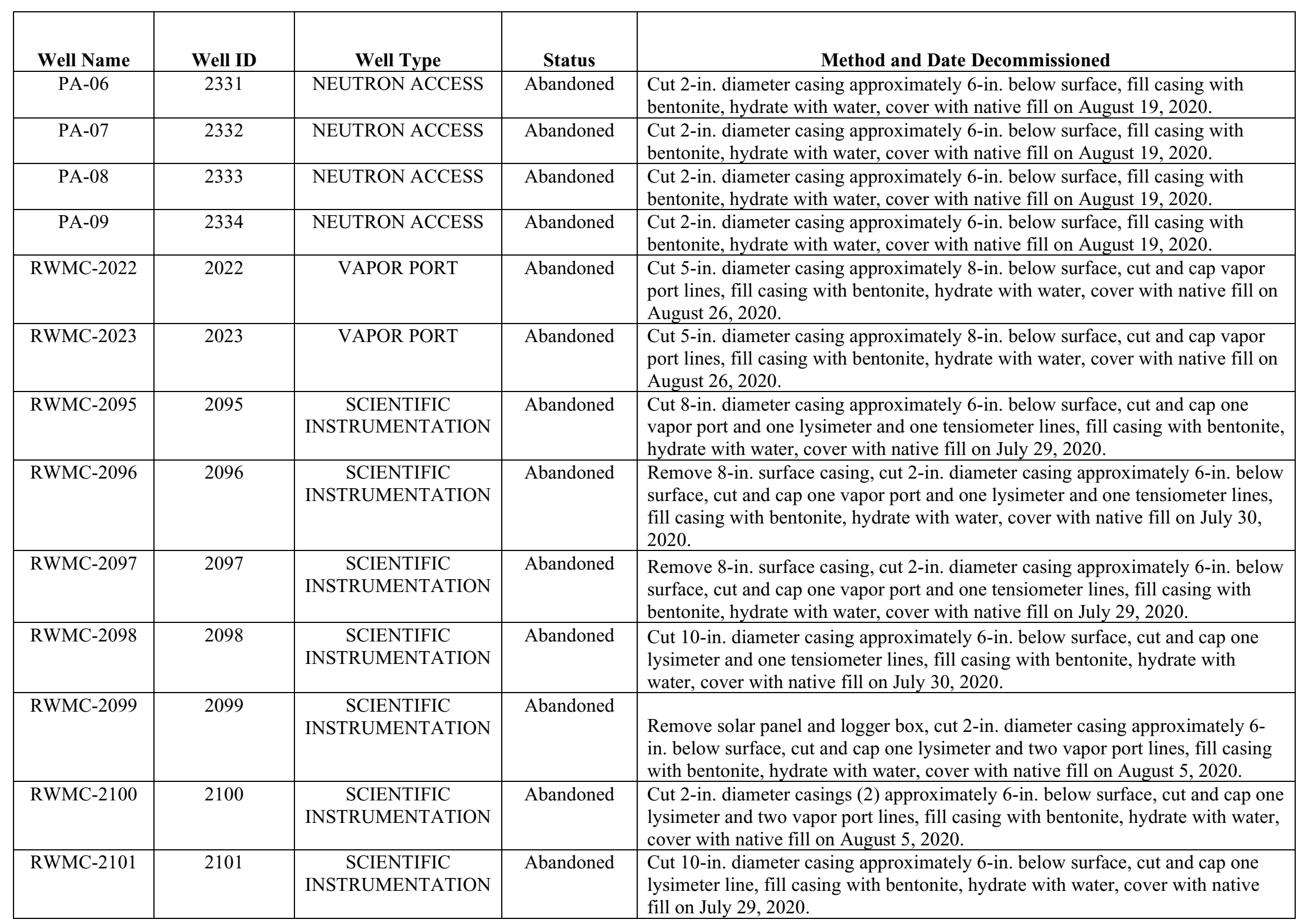


Table 11. Idaho National Laboratory wells and boreholes decommissioned in calendar year 2020 (cont.)

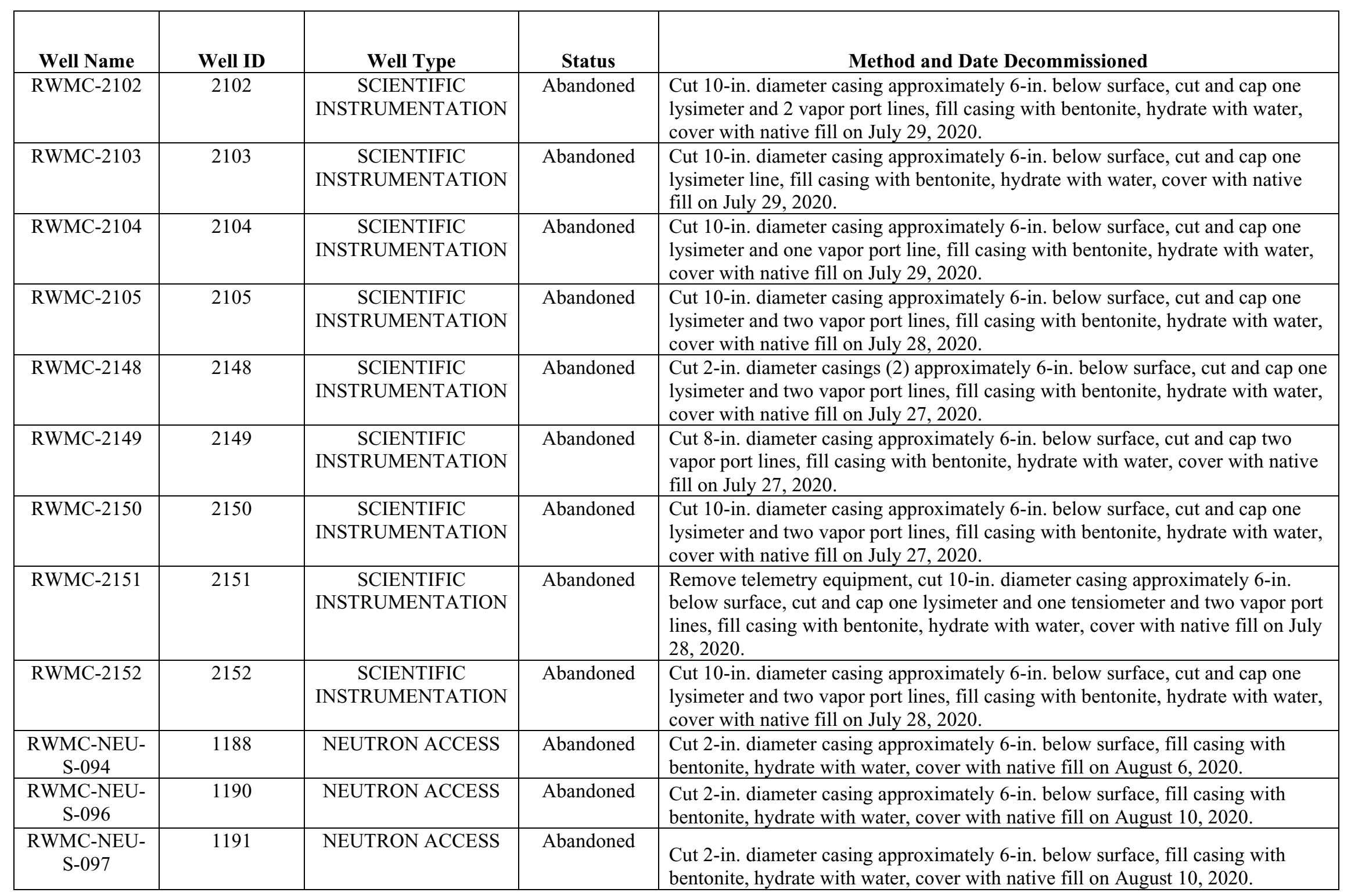


Table 11. Idaho National Laboratory wells and boreholes decommissioned in calendar year 2020 (cont.)

\begin{tabular}{|c|c|c|c|c|}
\hline Well Name & Well ID & Well Type & Status & Method and Date Decommissioned \\
\hline $\begin{array}{l}\text { RWMC-NEU- } \\
\text { S-099 }\end{array}$ & 1193 & NEUTRON ACCESS & Abandoned & $\begin{array}{l}\text { Cut } 2 \text {-in. diameter casing approximately } 6 \text {-in. below surface, cut and cap } 1 \\
\text { tensiometer line, fill casing with bentonite, hydrate with water, cover with native } \\
\text { fill on August } 6,2020 \text {. }\end{array}$ \\
\hline $\begin{array}{l}\text { RWMC-NEU- } \\
\text { S-104 }\end{array}$ & 1198 & NEUTRON ACCESS & Abandoned & $\begin{array}{l}\text { Cut } 2 \text {-in. diameter casing approximately } 6 \text {-in. below surface, cut and cap one } \\
\text { tensiometer line, fill casing with bentonite, hydrate with water, cover with native } \\
\text { fill on August } 10,2020 \text {. }\end{array}$ \\
\hline $\begin{array}{l}\text { RWMC-NEU- } \\
\text { S-107 }\end{array}$ & 1201 & NEUTRON ACCESS & Abandoned & $\begin{array}{l}\text { Cut } 2 \text {-in. diameter casing approximately } 6 \text {-in. below surface, fill casing with } \\
\text { bentonite, hydrate with water, cover with native fill on August } 5,2020 \text {. }\end{array}$ \\
\hline $\begin{array}{l}\text { RWMC-SCI- } \\
\text { S-114 }\end{array}$ & 1208 & $\begin{array}{c}\text { SCIENTIFIC } \\
\text { INSTRUMENTATION }\end{array}$ & Abandoned & $\begin{array}{l}\text { Cut } 8 \text {-in. diameter casing approximately } 6 \text {-in. below surface, cut and cap one } \\
\text { lysimeter line, fill casing with bentonite, hydrate with water, cover with native } \\
\text { fill on August } 5,2020 \text {. }\end{array}$ \\
\hline $\begin{array}{l}\text { RWMC-SCI- } \\
\text { S-SVR12-1-L1 }\end{array}$ & 1754 & $\begin{array}{c}\text { SCIENTIFIC } \\
\text { INSTRUMENTATION }\end{array}$ & Abandoned & $\begin{array}{l}\text { Cut } 5 \text {-in. diameter casing approximately } 8 \text {-in. below surface, cut and cap vapor } \\
\text { port and lysimeter lines, fill casing with bentonite, hydrate with water, cover with } \\
\text { native fill on August } 26,2020 \text {. }\end{array}$ \\
\hline $\begin{array}{l}\text { RWMC-SCI- } \\
\text { S-SVR12-1-T2 }\end{array}$ & 1652 & $\begin{array}{c}\text { SCIENTIFIC } \\
\text { INSTRUMENTATION }\end{array}$ & Abandoned & $\begin{array}{l}\text { Cut } 5 \text {-in. diameter casing approximately } 8 \text {-in. below surface, cut and cap } \\
\text { tensiometer line, fill casing with bentonite, hydrate with water, cover with native } \\
\text { fill on August } 26,2020 \text {. }\end{array}$ \\
\hline $\begin{array}{l}\text { RWMC-SCI- } \\
\text { S-SVR12-3- } \\
\text { VP1 }\end{array}$ & 1730 & $\begin{array}{c}\text { SCIENTIFIC } \\
\text { INSTRUMENTATION }\end{array}$ & Abandoned & $\begin{array}{l}\text { Cut } 5 \text {-in. diameter casing approximately } 8 \text {-in. below surface, cut and cap two } \\
\text { vapor port and lines, fill casing with bentonite, hydrate with water, cover with } \\
\text { native fill on August } 26,2020 \text {. }\end{array}$ \\
\hline $\begin{array}{l}\text { RWMC-SCI- } \\
\text { S-SVR12-3- } \\
\text { VP2 }\end{array}$ & 1731 & $\begin{array}{c}\text { SCIENTIFIC } \\
\text { INSTRUMENTATION }\end{array}$ & Abandoned & $\begin{array}{l}\text { Cut } 5 \text {-in. diameter casing approximately } 8 \text {-in. below surface, cut and cap two } \\
\text { vapor port and lines, fill casing with bentonite, hydrate with water, cover with } \\
\text { native fill on August } 26,2020 \text {. }\end{array}$ \\
\hline $\begin{array}{l}\text { RWMC-SCI- } \\
\text { S-SVR12-3- } \\
\text { VP3 }\end{array}$ & 1732 & $\begin{array}{c}\text { SCIENTIFIC } \\
\text { INSTRUMENTATION }\end{array}$ & Abandoned & $\begin{array}{l}\text { Cut } 5 \text {-in. diameter casing approximately } 8 \text {-in. below surface, cut and cap two } \\
\text { vapor port and lines, fill casing with bentonite, hydrate with water, cover with } \\
\text { native fill on August } 26,2020 \text {. }\end{array}$ \\
\hline $\begin{array}{l}\text { RWMC-SCI- } \\
\text { S-SVR-12-MB }\end{array}$ & 1705 & $\begin{array}{c}\text { SCIENTIFIC } \\
\text { INSTRUMENTATION }\end{array}$ & Abandoned & $\begin{array}{l}\text { Cut } 5 \text {-in. diameter casing approximately } 8 \text {-in. below surface, cut and cap } \\
\text { moisture probe line, fill casing with bentonite, hydrate with water, cover with } \\
\text { native fill on August } 26,2020 \text {. }\end{array}$ \\
\hline
\end{tabular}


Table 11. Idaho National Laboratory wells and boreholes decommissioned in calendar year 2020 (cont.)

\begin{tabular}{|c|c|c|c|c|}
\hline Well Name & Well ID & Well Type & Status & \multicolumn{1}{c|}{ Method and Date Decommissioned } \\
\hline TEN-8 & 1946 & $\begin{array}{c}\text { SCIENTIFIC } \\
\text { INSTRUMENTATION }\end{array}$ & Abandoned & $\begin{array}{l}\text { Remove four tensiometers from well, cut 8-in. diameter casing approximately 6- } \\
\text { in. below surface, fill casing with bentonite, hydrate with water, cover with } \\
\text { native fill on August 6, 2020. }\end{array}$ \\
\hline TEN-9 & 1947 & $\begin{array}{c}\text { SCIENTIFIC } \\
\text { INSTRUMENTATION }\end{array}$ & Abandoned & $\begin{array}{l}\text { Remove three tensiometers from borehole, cut 8-in. diameter casing } \\
\text { approximately 6-in. below surface, fill casing with bentonite, hydrate with water, } \\
\text { cover with native fill on August 10, 2020. }\end{array}$ \\
\hline W-05 & 578 & $\begin{array}{c}\text { SCIENTIFIC } \\
\text { INSTRUMENTATION }\end{array}$ & Abandoned & $\begin{array}{l}\text { Cut 8-in. diameter casing to approximately 8-in. below surface, cut and cap three } \\
\text { lysimeter lines, fill casing with bentonite, hydrate with water, cover with native } \\
\text { fill on August 5, 2020. }\end{array}$ \\
\hline W-06 & 579 & $\begin{array}{c}\text { SCIENTIFIC } \\
\text { INSTRUMENTATION }\end{array}$ & Abandoned & $\begin{array}{l}\text { Cut 8-in. diameter casing to approximately 8-in. below surface, cut and cap three } \\
\text { tensiometer and two vapor port and one lysimeter lines, fill casing with } \\
\text { bentonite, hydrate with water, cover with native fill on August 26, 2020. }\end{array}$ \\
\hline W-09 & 581 & $\begin{array}{c}\text { SCIENTIFIC } \\
\text { INSTRUMENTATION }\end{array}$ & Abandoned & $\begin{array}{l}\text { Cut 10-in. diameter casing to approximately 8-in. below surface, cut and cap two } \\
\text { vapor port and 12 data logger lines, fill casing with bentonite, hydrate with water, } \\
\text { cover with native fill on August 6, 2020. }\end{array}$ \\
\hline W-13 & 585 & $\begin{array}{c}\text { SCIENTIFIC } \\
\text { INSTRUMENTATION }\end{array}$ & Abandoned & $\begin{array}{l}\text { Cut 10-in. diameter casing to approximately 8-in. below surface, cut and cap four } \\
\text { vapor port and 15 data logger lines, fill casing with bentonite, hydrate with water, } \\
\text { cover with native fill on August 10, 2020. }\end{array}$ \\
\hline W-23 & 592 & $\begin{array}{c}\text { SCIENTIFIC } \\
\text { INSTRUMENTATION }\end{array}$ & Abandoned & $\begin{array}{l}\text { Cut 8-in. diameter casing to approximately 8-in. below surface, cut and cap six } \\
\text { vapor port and two data logger lines, fill casing with bentonite, hydrate with } \\
\text { water, cover with native fill on August 10, 2020. }\end{array}$ \\
\hline
\end{tabular}




\section{REFERENCES}

1. Department of Justice, Environment and Natural Resources Division, 1990, "Water Rights Agreement between the State of Idaho and the United States, for the United States Department of Energy," CCN 23795.

2. District Court-SRBA, Fifth Judicial District, Twin Falls County, Idaho, Order of Partial Decree for Water Right 34-10901 (United States Department of Energy, Idaho National Engineering and Environmental Laboratory), Case No. 39576, June 20, 2003, CCN 23795.

3. District Court-SRBA, Fifth Judicial District, Twin Falls County, Idaho, Final Unified Decree, Case No. 39576, August 25, 2014.

4. DOE-ID, 2019, "Preliminary Decommission and Demolition Plan for Structures within the Design Footprint of the Operable Unit 7-13/14 Phase 3 Subsurface Disposal Area Evapotranspiration Surface Barrier," DOE/ID-12000, Rev. 0, U.S. Department of Energy Idaho Operations Office, August 2019.

5. IDAPA 37.03.09, "Well Construction Standards Rules," 2009.

6. Lewis, M. G., BEA to S. Brennan, DOE-ID, January 13, 2020, "January 7, 2020, Meeting with Ryan Tracy, IDWR," CCN 246251.

7. Reno, S. L., Fluor Idaho, to R. Tracy, IDWR, June 18, 2020, "Decommissioning Notification for Fifty-Two Wells at the Idaho National Laboratory Site," CCN 325357.

8. Stenzel, J. A., BEA, to D. Dunn, IDWR, December 22, 2009, "Record of Meeting Concerning Well Permitting, Maintenance, and Decommissioning at the Idaho National Laboratory," CCN 219522.

9. Street, L.V., INEEL, to D. Dunn, IDWR, September 4, 2001, "INEEL Comprehensive Well Surveys and Annual Water Use Reports," CCN 25370. 


\section{Appendix A}

\section{Maps and Construction Diagrams for New Wells Completed or Modified in CY 2019 and CY 2020}




\section{Appendix A}

Maps and Construction Diagrams for New Wells Completed or Modified in CY 2019 and CY 2020

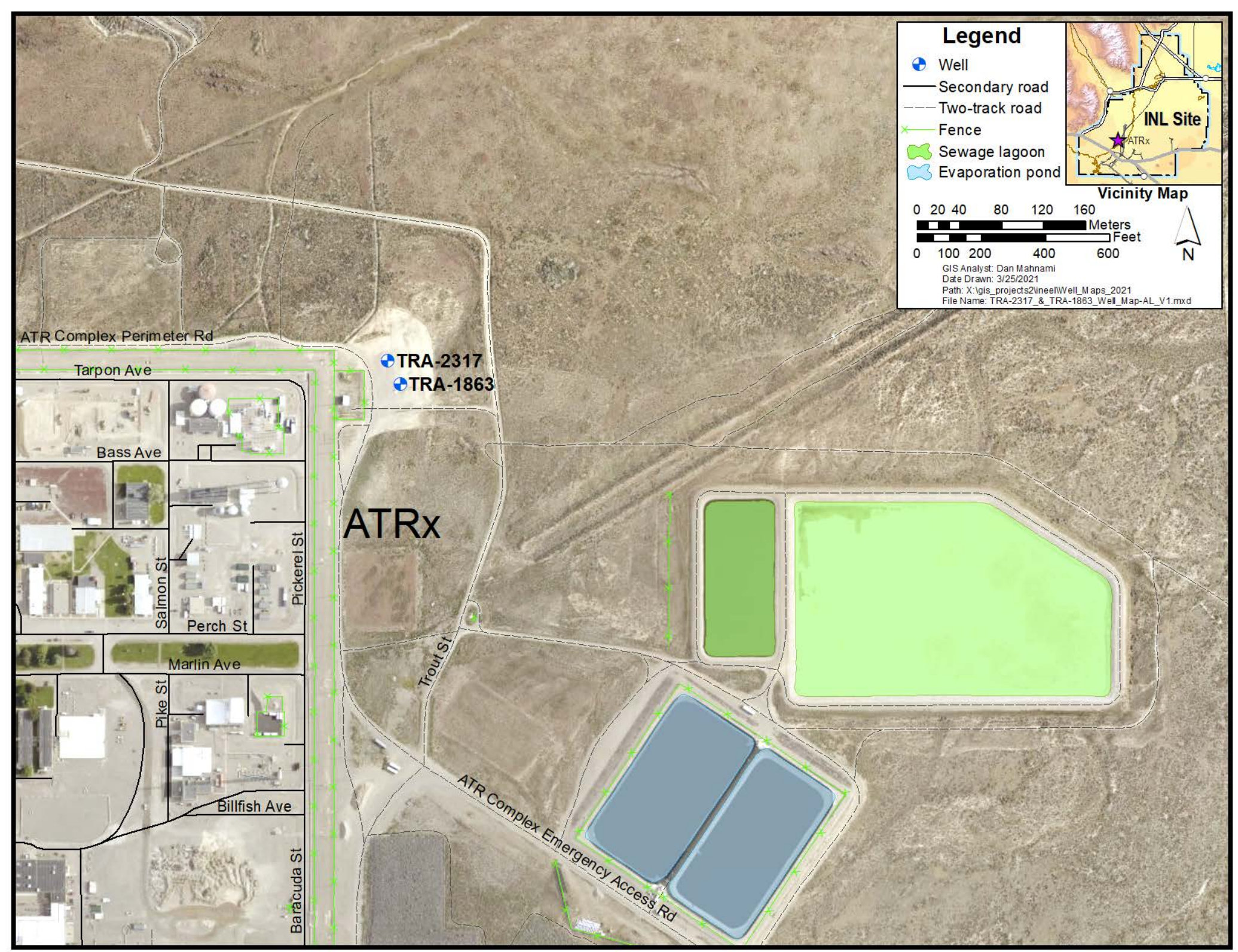

Figure A-1. Map showing location of newly constructed well TRA-2317. 
WELL NAME: TRA-2317

WELL ID: 2317

Faclity: ATR Complex

Well Type: Potable/Drinking

Well Status: Active

Year Drilled. 2019

Total Depth: $590^{\prime}$ BLS

Completion Depth: $577^{\prime}$ BLS
Driler. Thomas Drilling

Geologist:Thomas Drilling

Dril Method:Air Rotary

Drill Fluid: NF

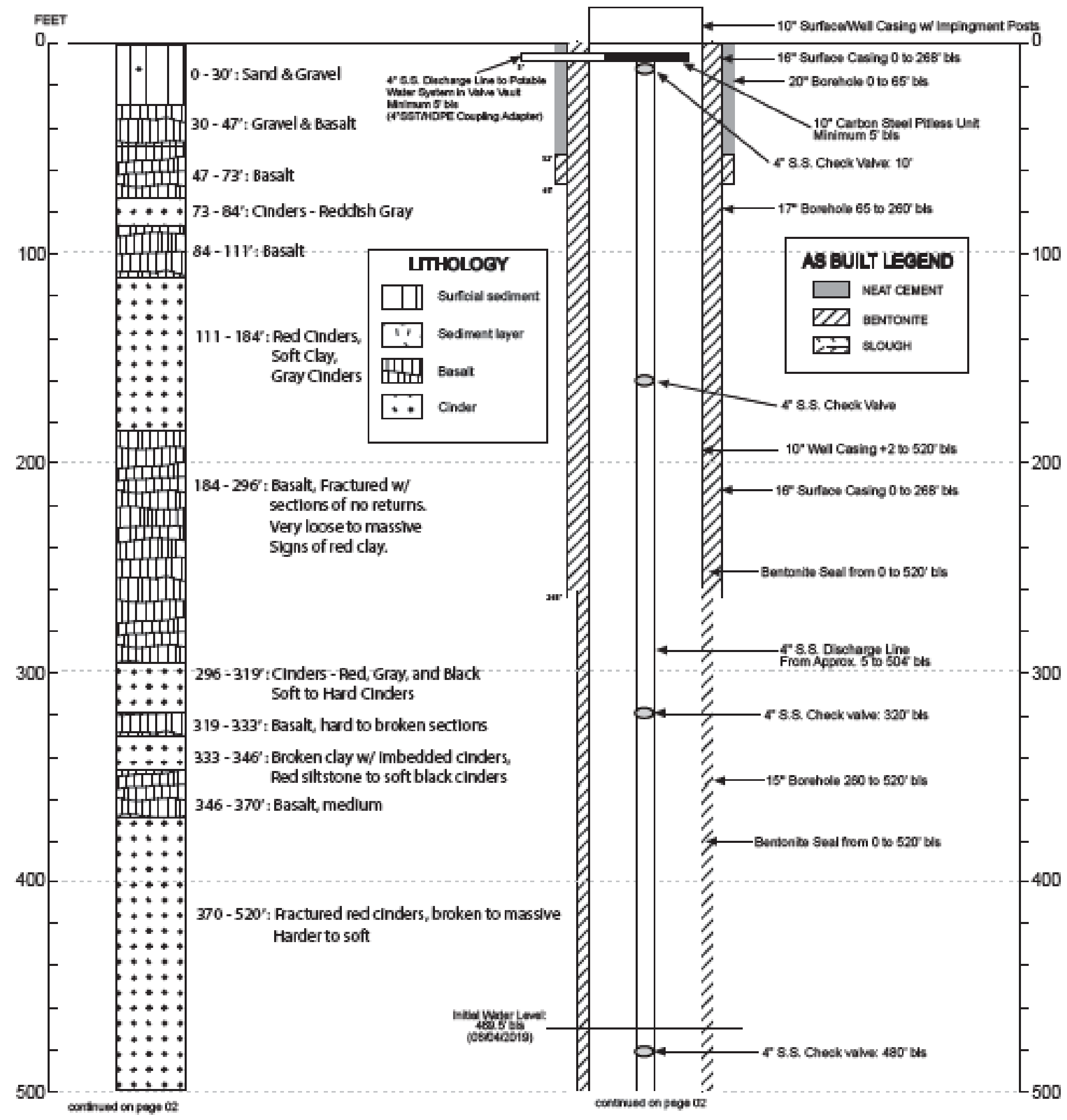

Figure A-2. Construction diagram of new well TRA-2317. 
Page 2 of 2

WELL NAME: TRA-2317

Drawing Rev Date: $\underline{02 / 16 / 2021}$

WEU ID- 2317

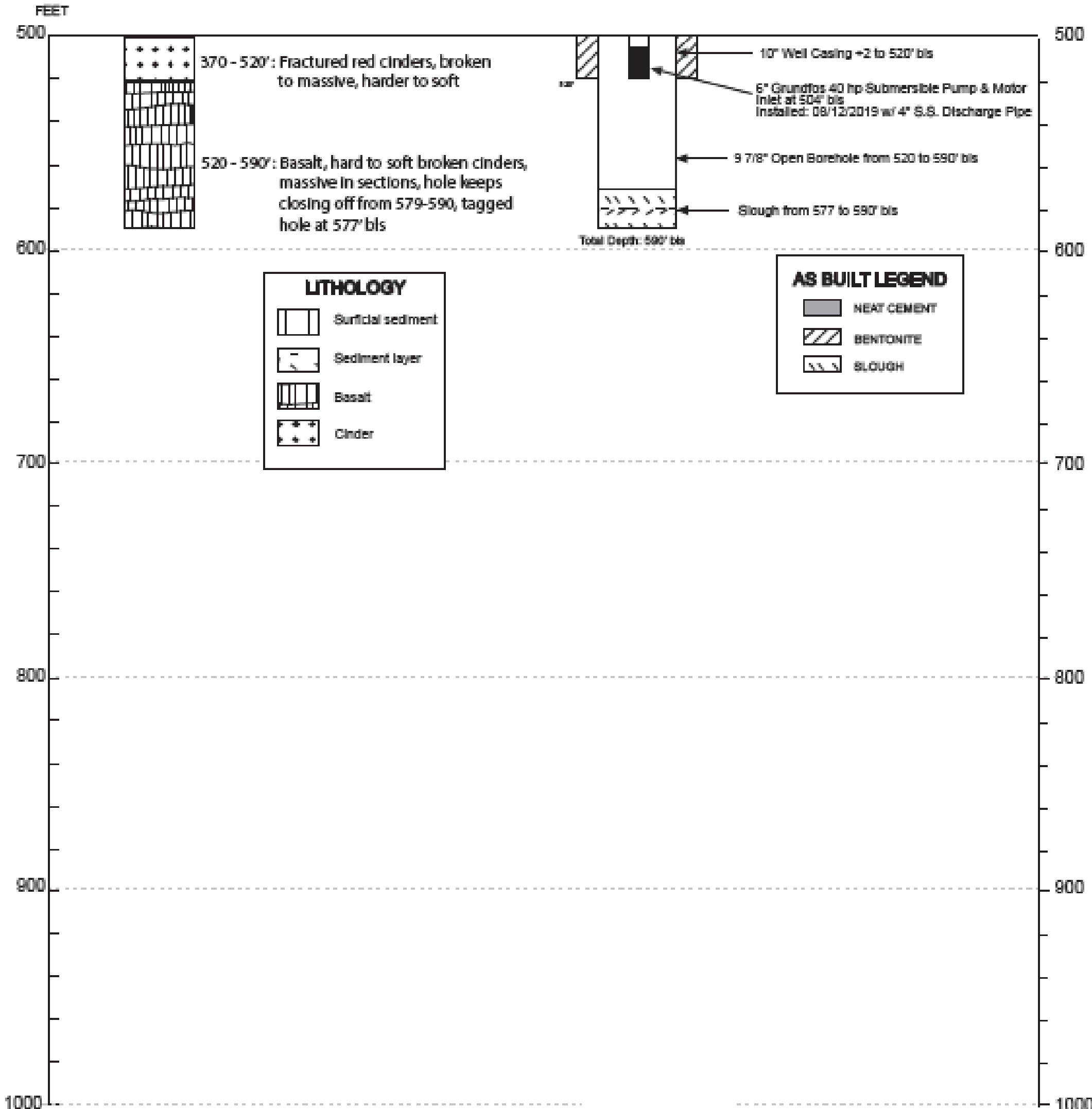

Figure A-2. (continued) 


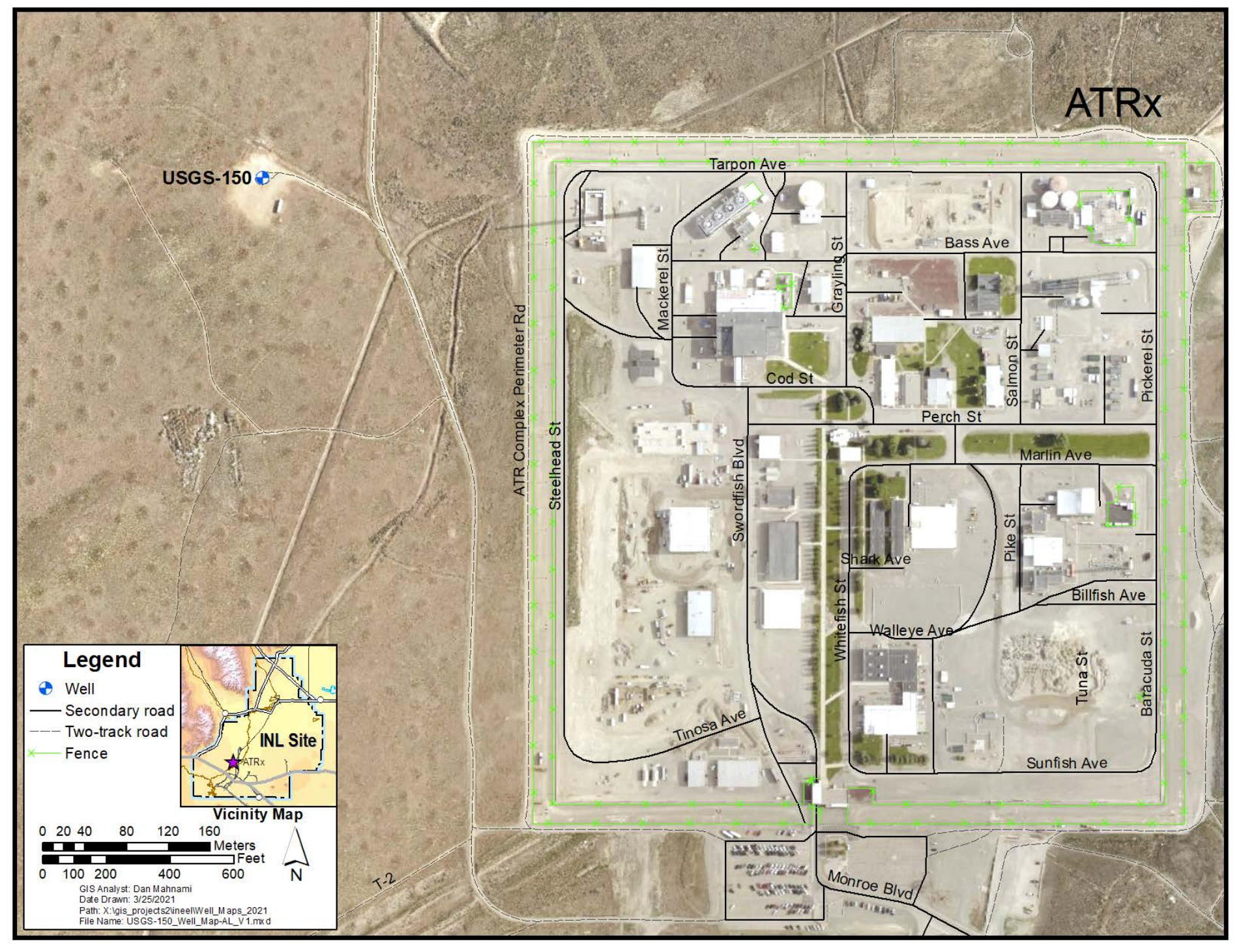

Figure A-3. Map showing location of newly constructed well USGS-150. 

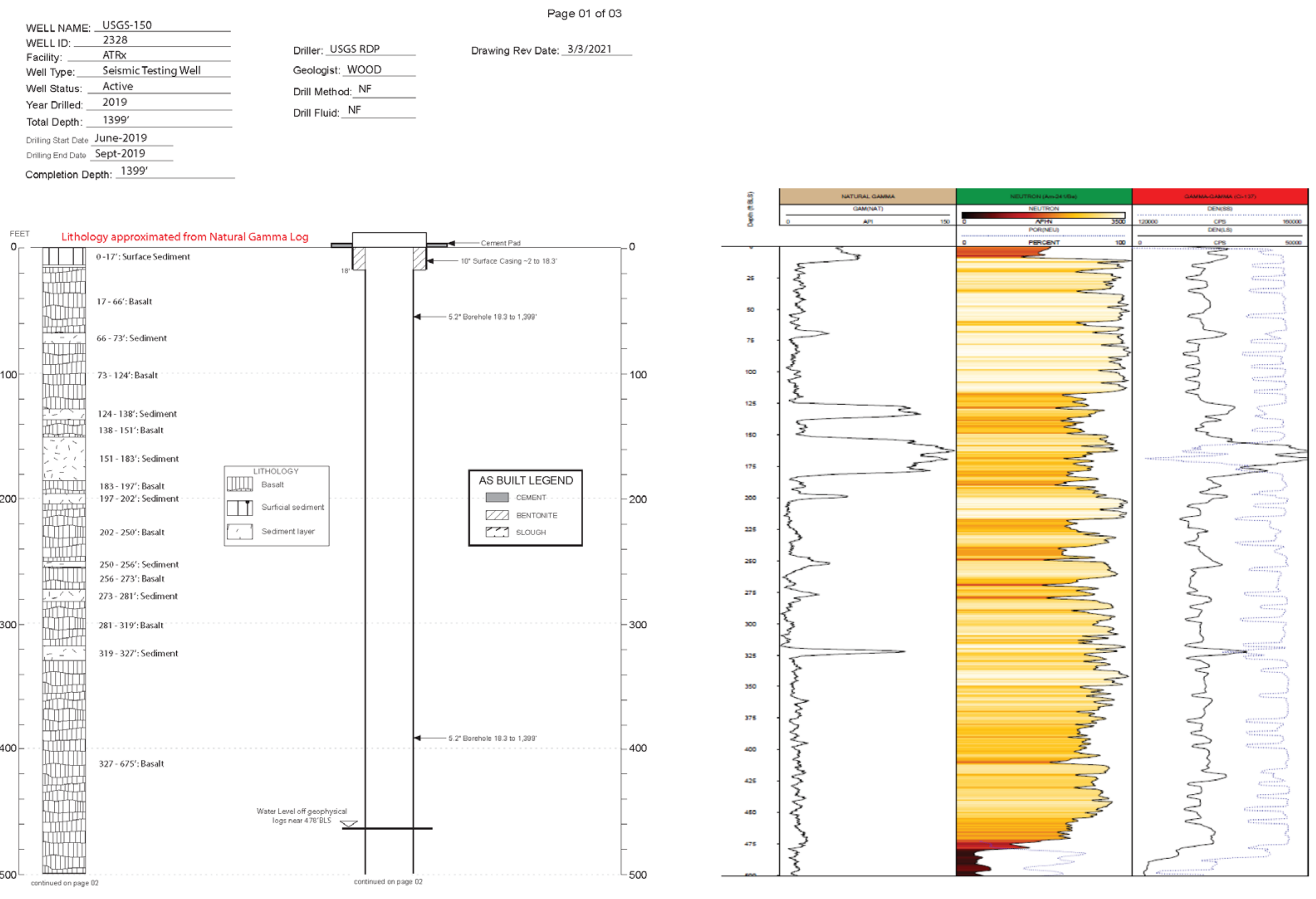

Figure A-4. Construction diagram of new well USGS-150. 


$$
T T
$$


WELL NAME: $\frac{\text { USGS-150 }}{2328}$
WELL ID:

Page 03 of 03

Drawing Rev Date: 3/3/2021

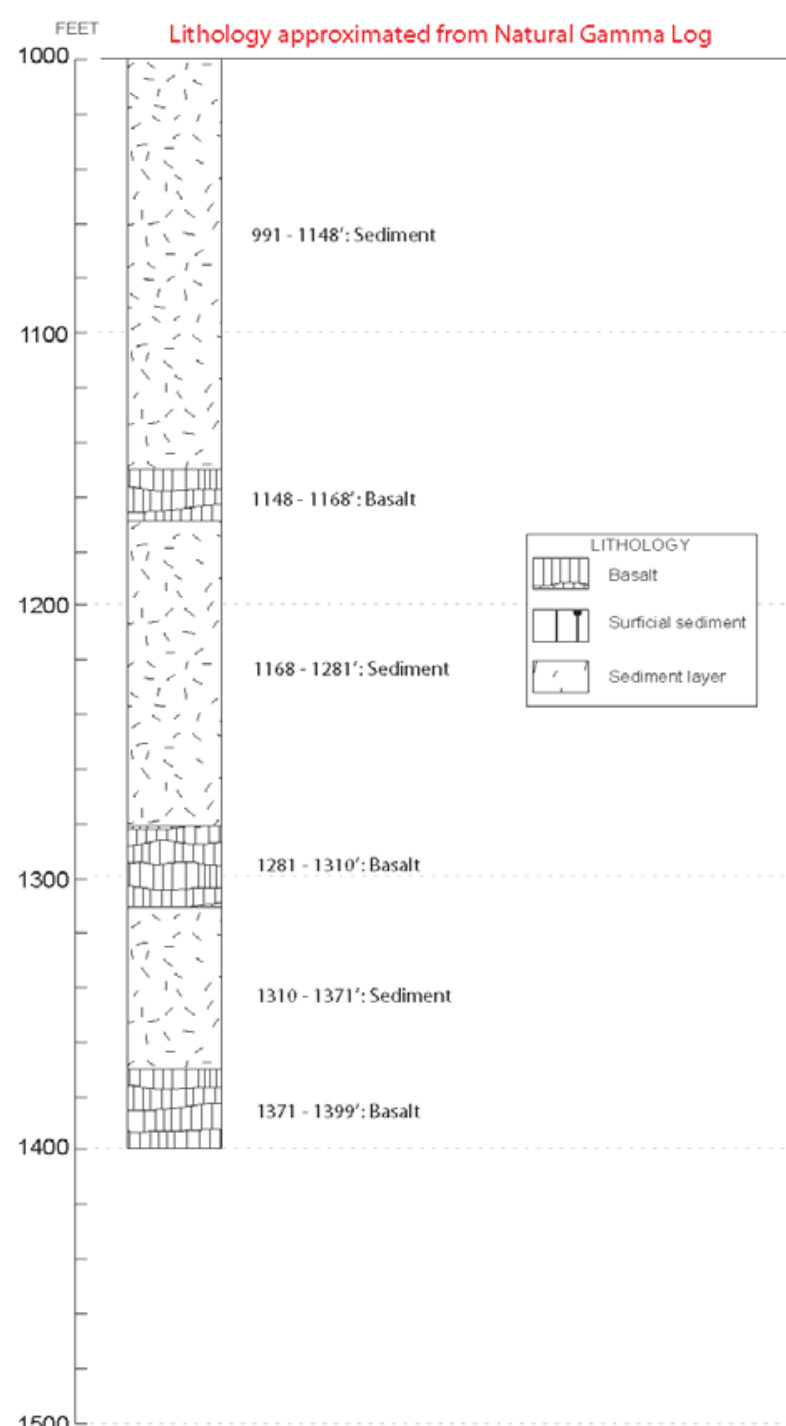

1000
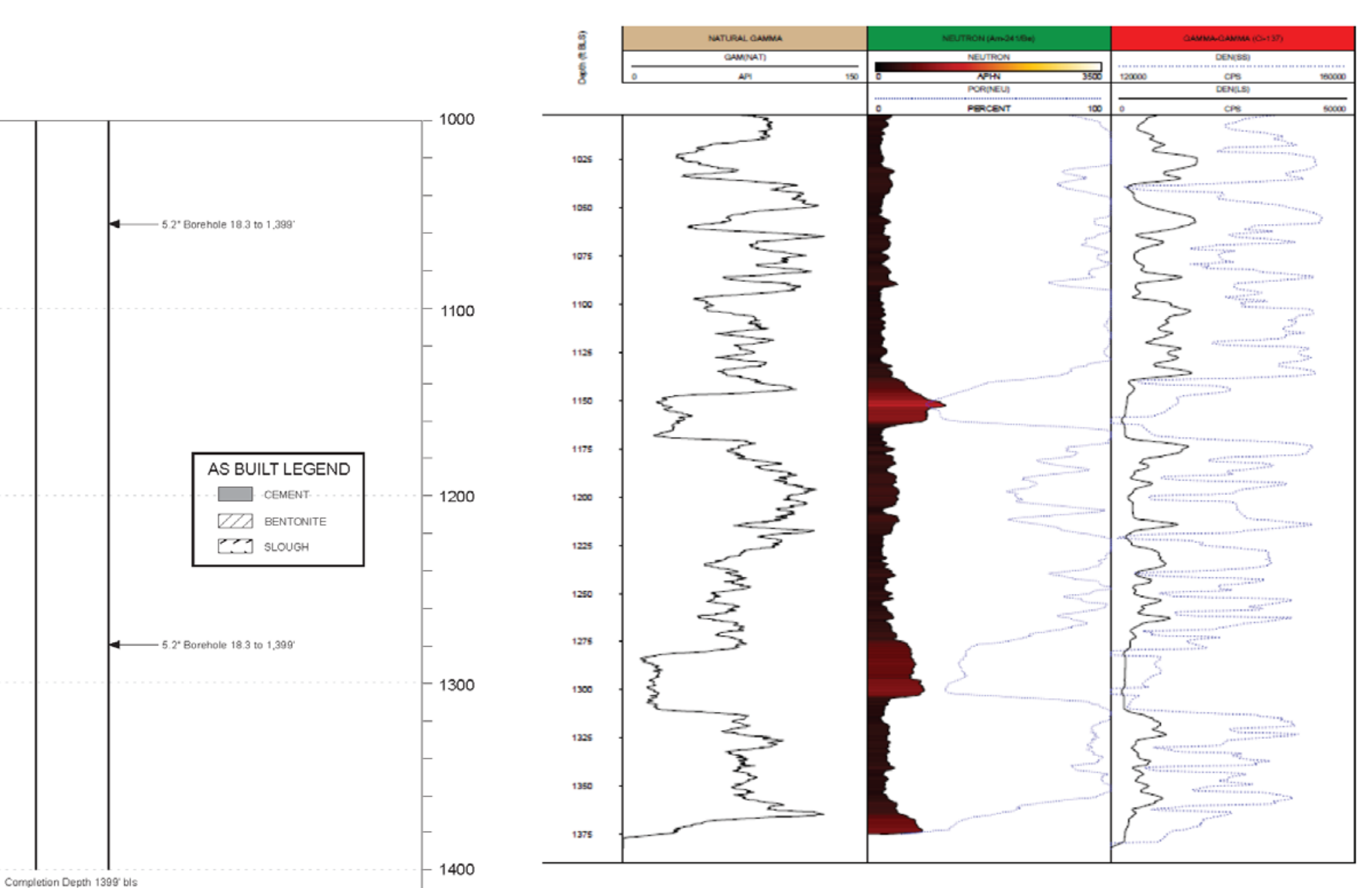

1500

Figure A-4. (continued) 


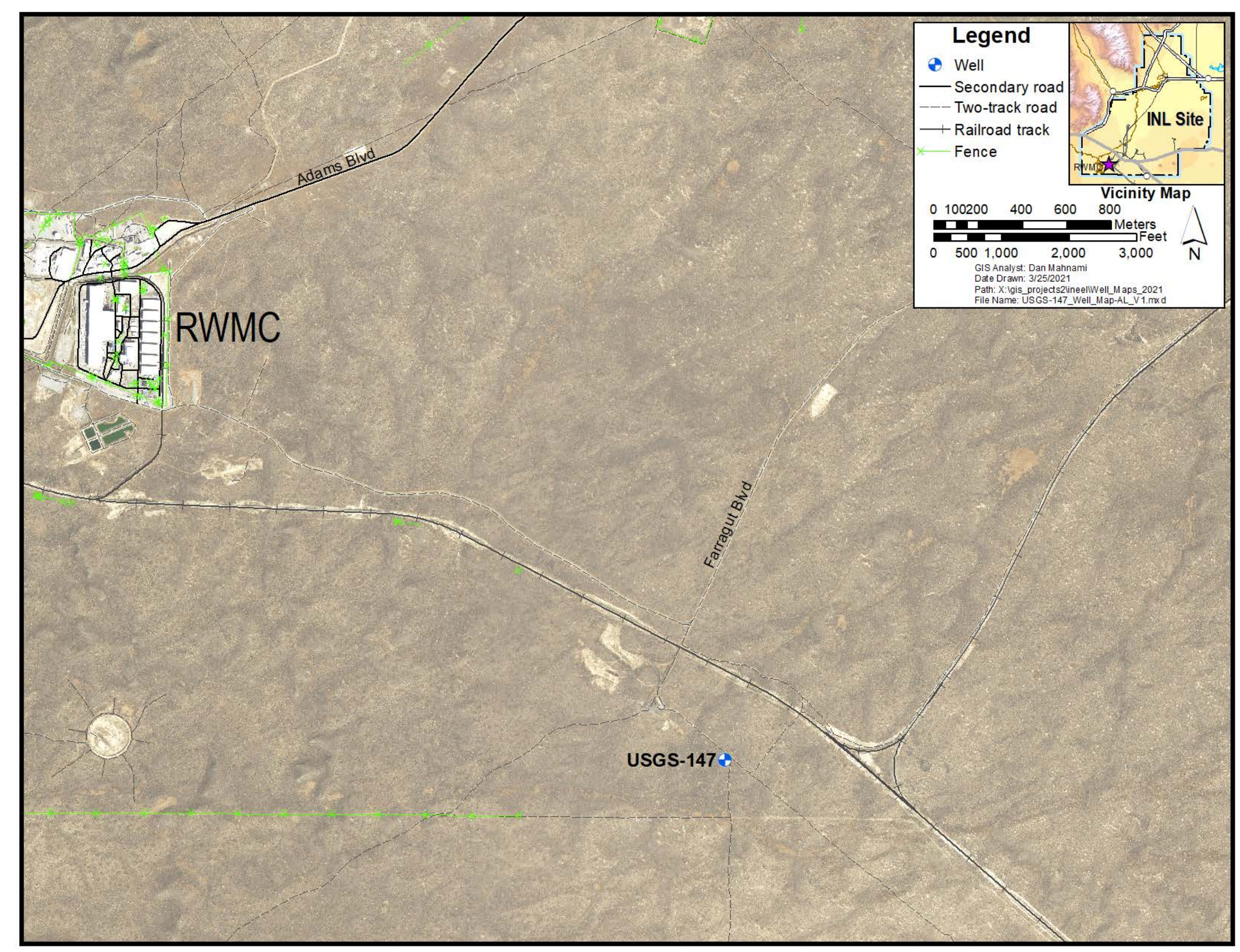

Figure A-5. Map showing location of newly modified well USGS-147. 


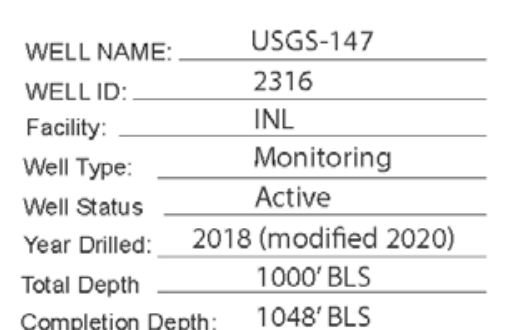

Driller- USGS Geologist: B. Twining Drill Method: Air-Rotary Drill Fluid: Foam

Drilling Start Date $9 / 4 / 2018$ Drilling End Date 7/9/2020
Page 1 of 5

Drawing Date: 02/22/2021

USGS deepened from $751^{\prime}$ to 1048 from May 12 - July 9,2020 . Bridge obstruction near $817^{\prime}$ BLS
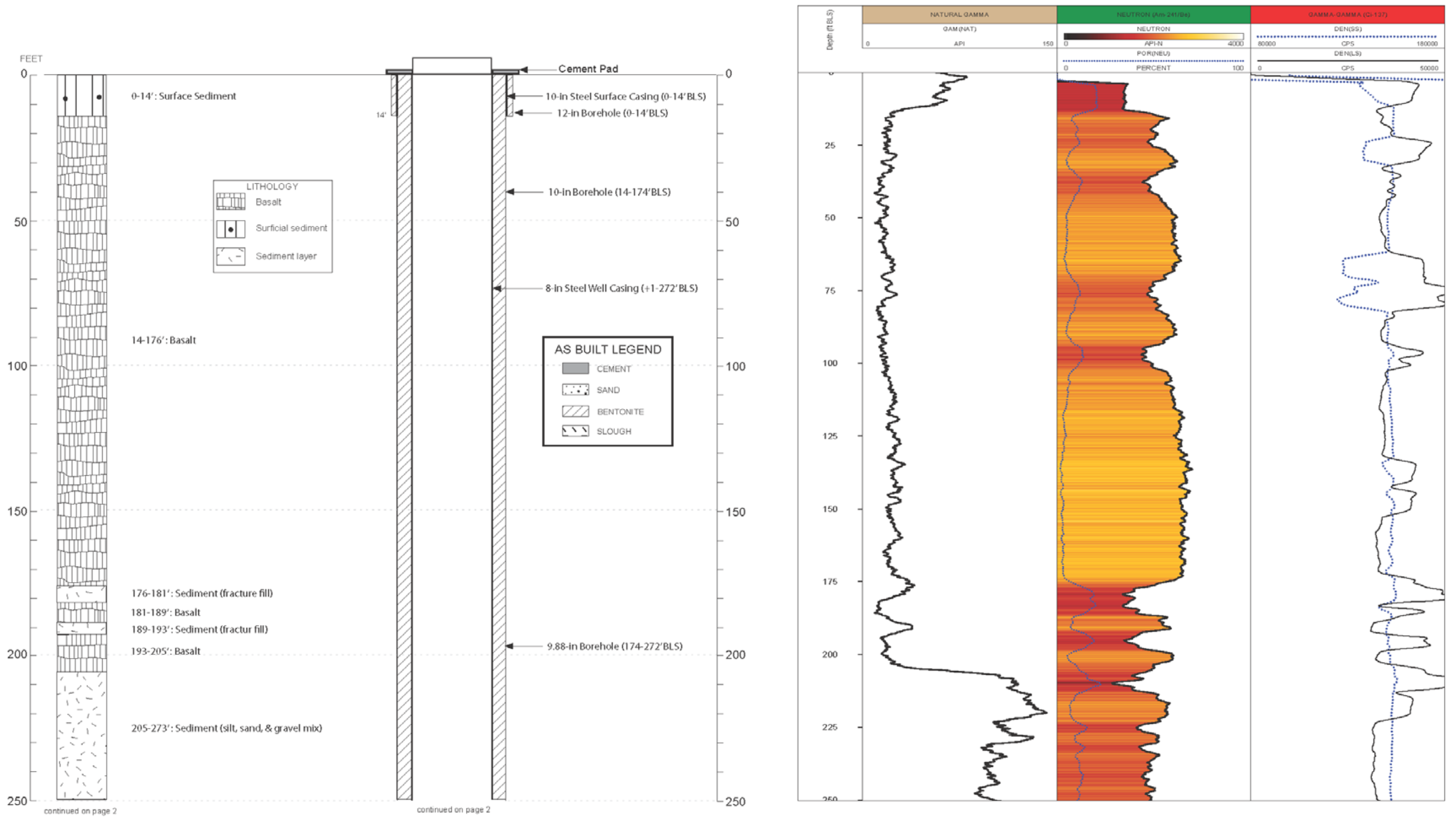

Figure A-6. Construction diagram of modified well USGS-147. 
WELL NAME: USGS-147

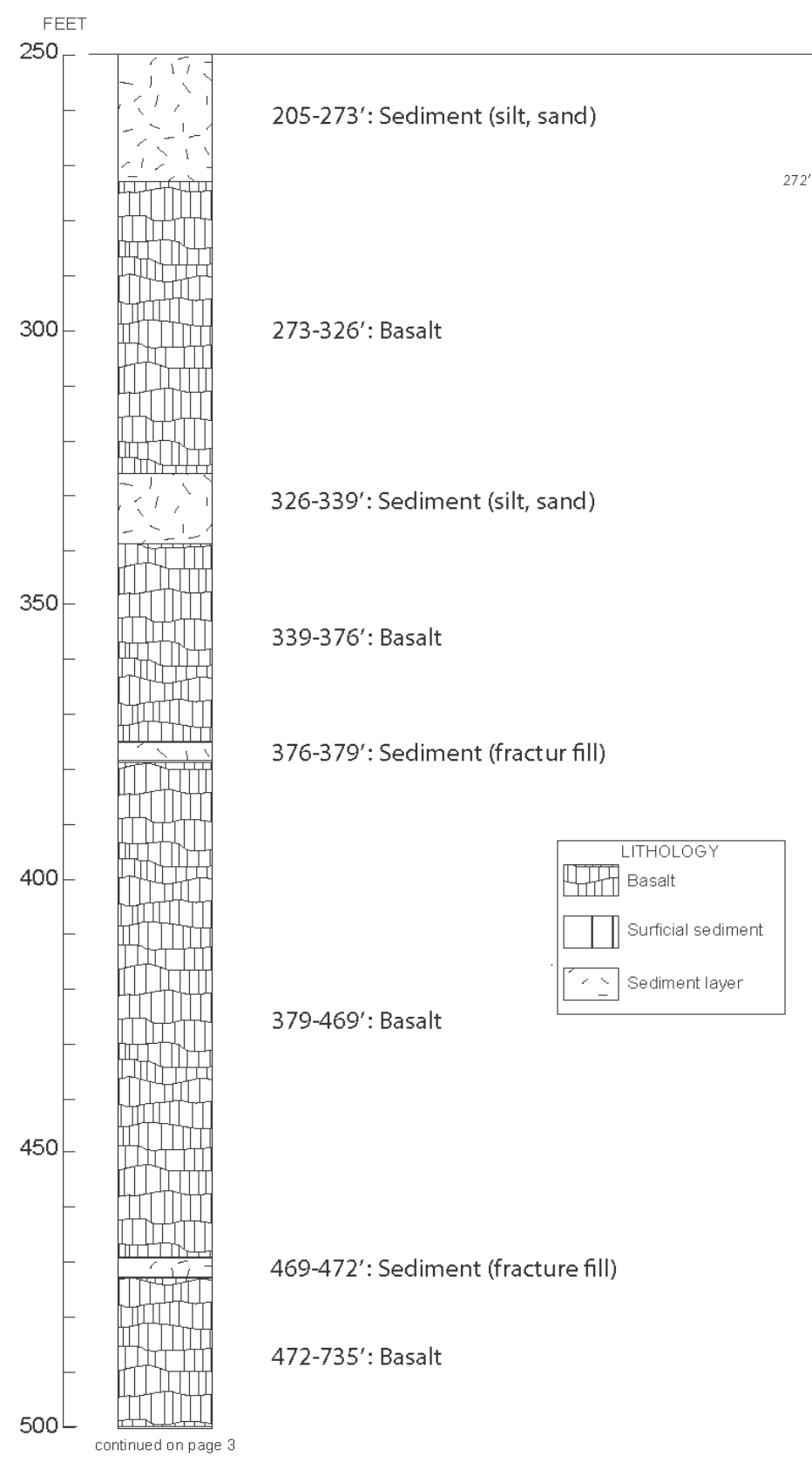

Page 2 of 5

Drawing Date: 02/22/2021
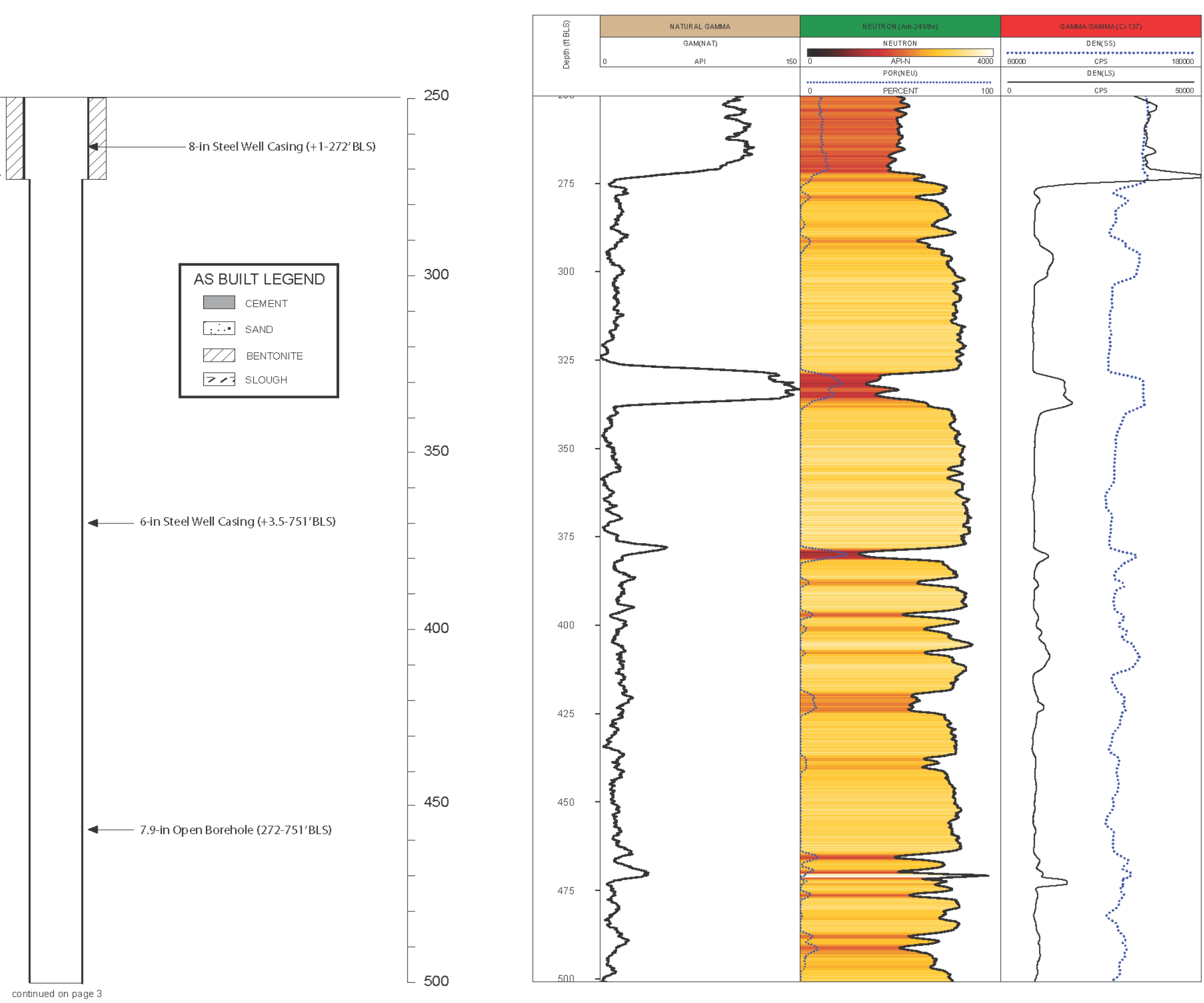

Figure A-6. (continued). 
WELL NAME: USGS-147

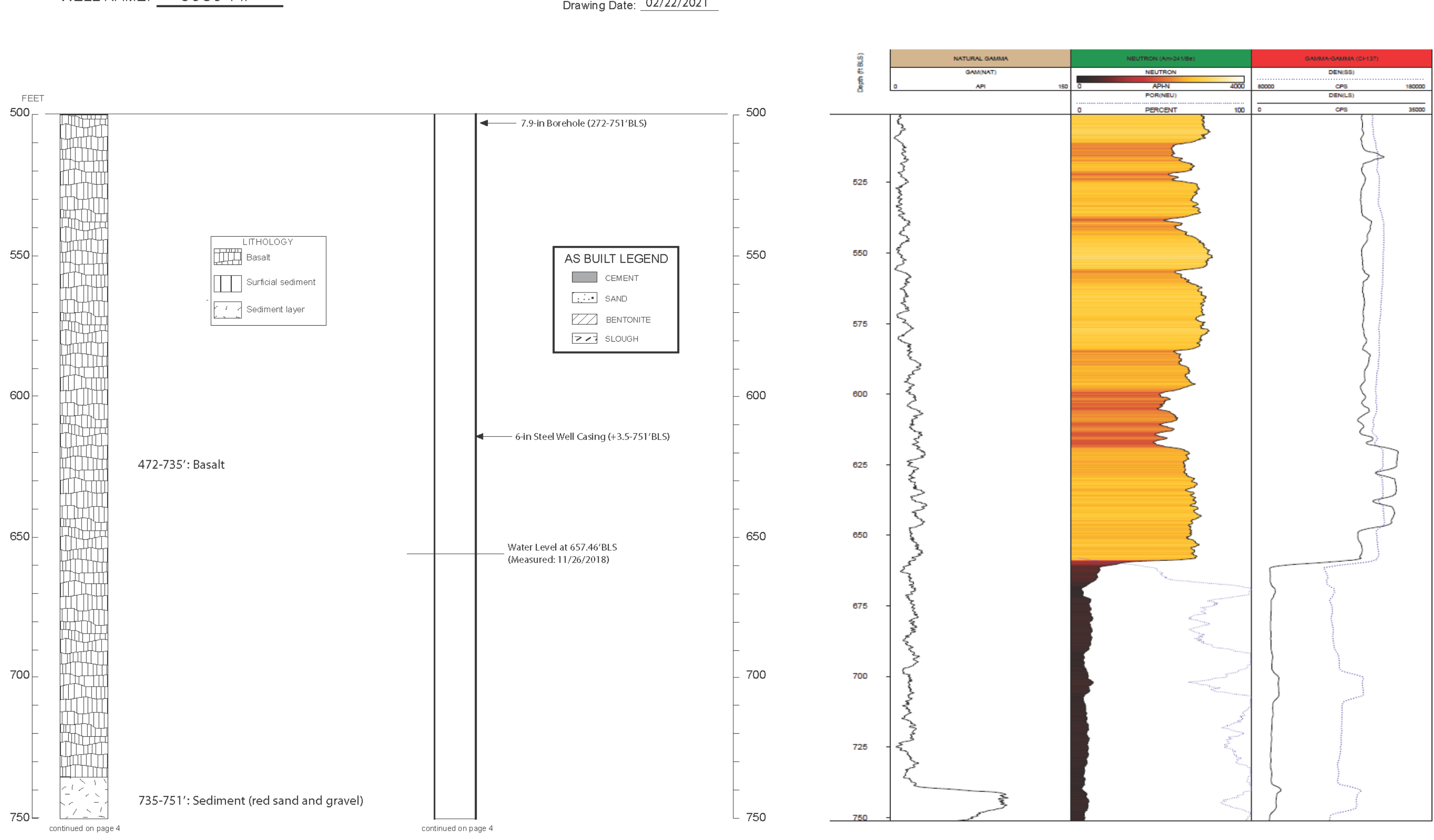

Page 3 of 5

Drawing Date: 02/22/2021 
WELL NAME

USGS-147

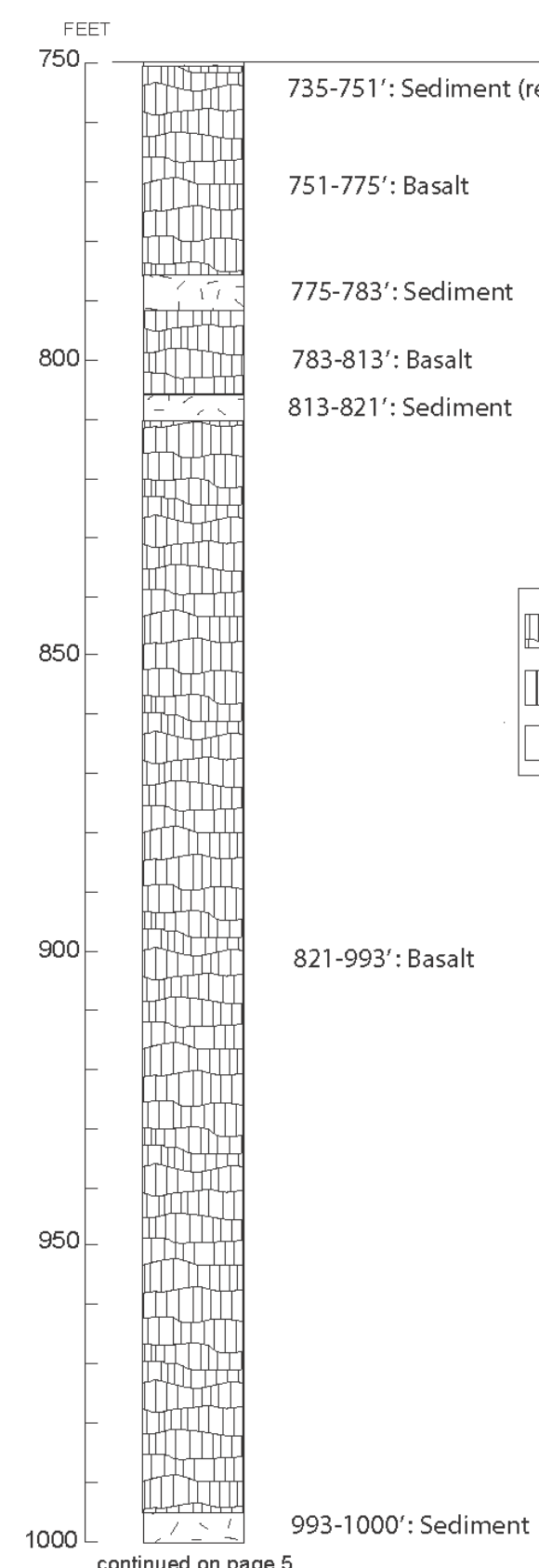

993-1000': Sediment
Page 4 of 5

Drawing Date: 02/22/2021

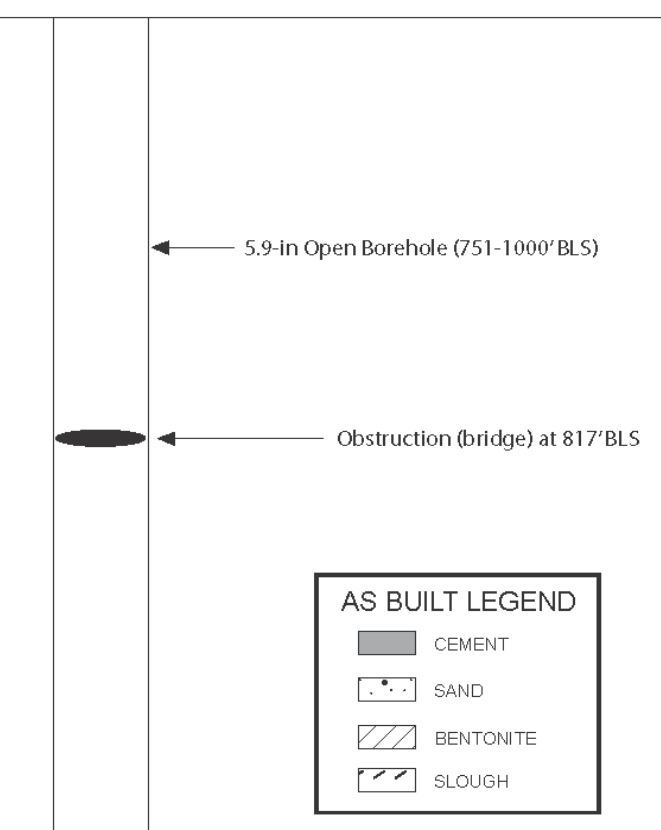

750

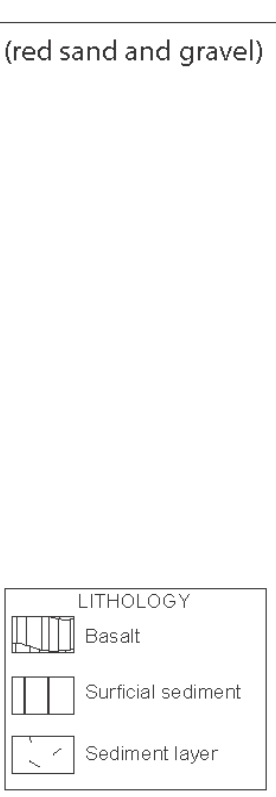

$x^{2}$

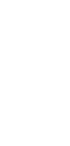

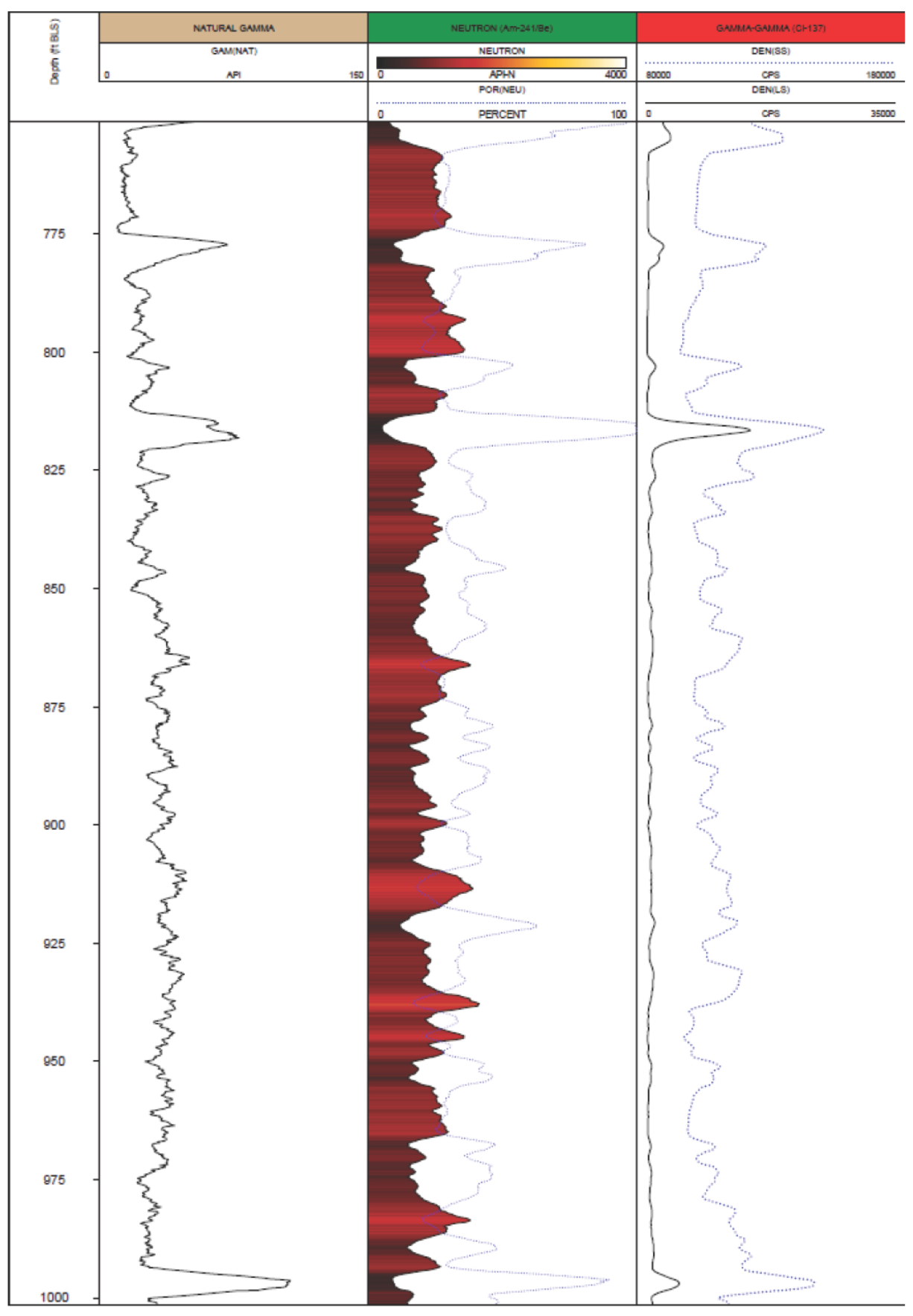


WELL NAME: USGS-147

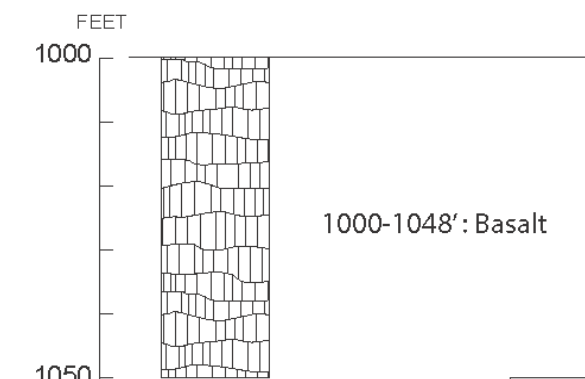

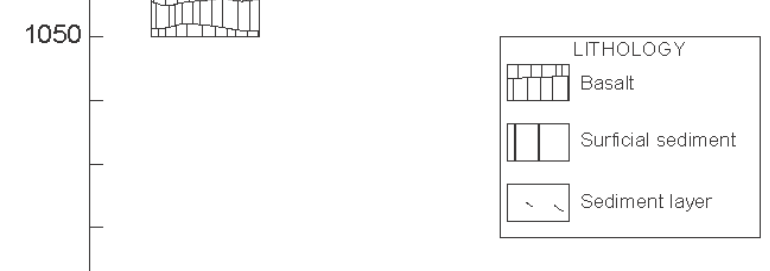

1100

1100

1200

1250
Page 5 of 5

Drawing Date: 02/22/2021

1000

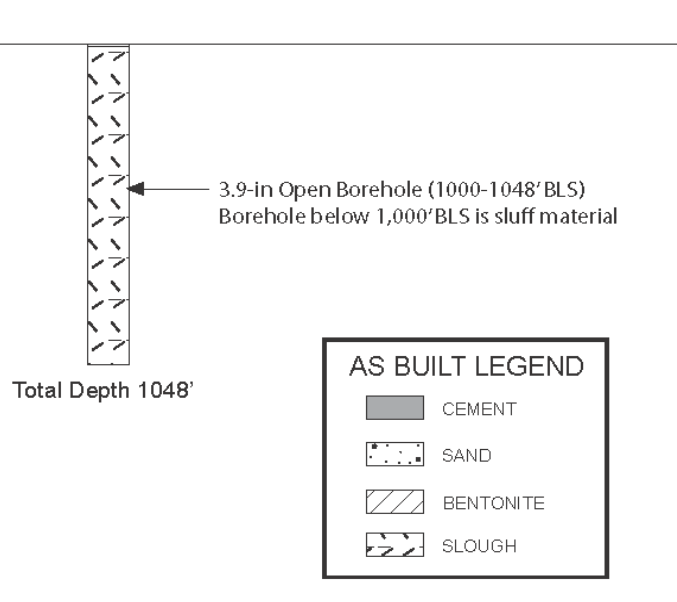

1050

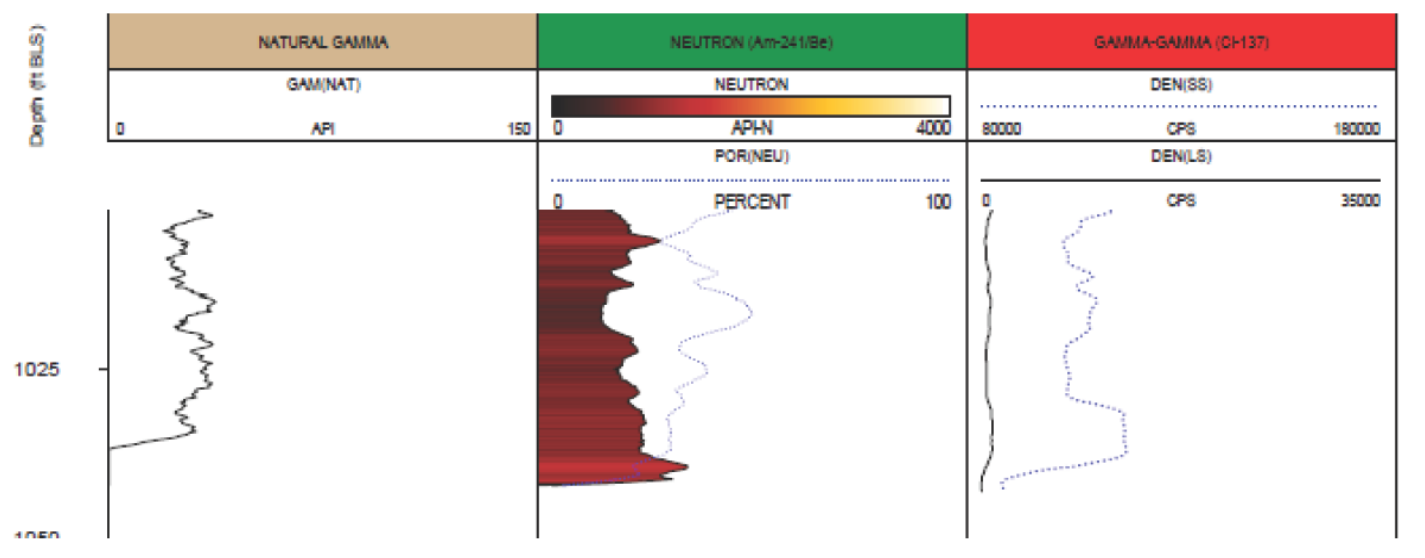


Appendix B

Maps and Construction Diagrams for Wells and Boreholes Decommissioned (Abandoned) in CY 2020 


\section{Appendix B}

Maps and Construction Diagrams for Wells and Boreholes Decommissioned (Abandoned) in CY 2020

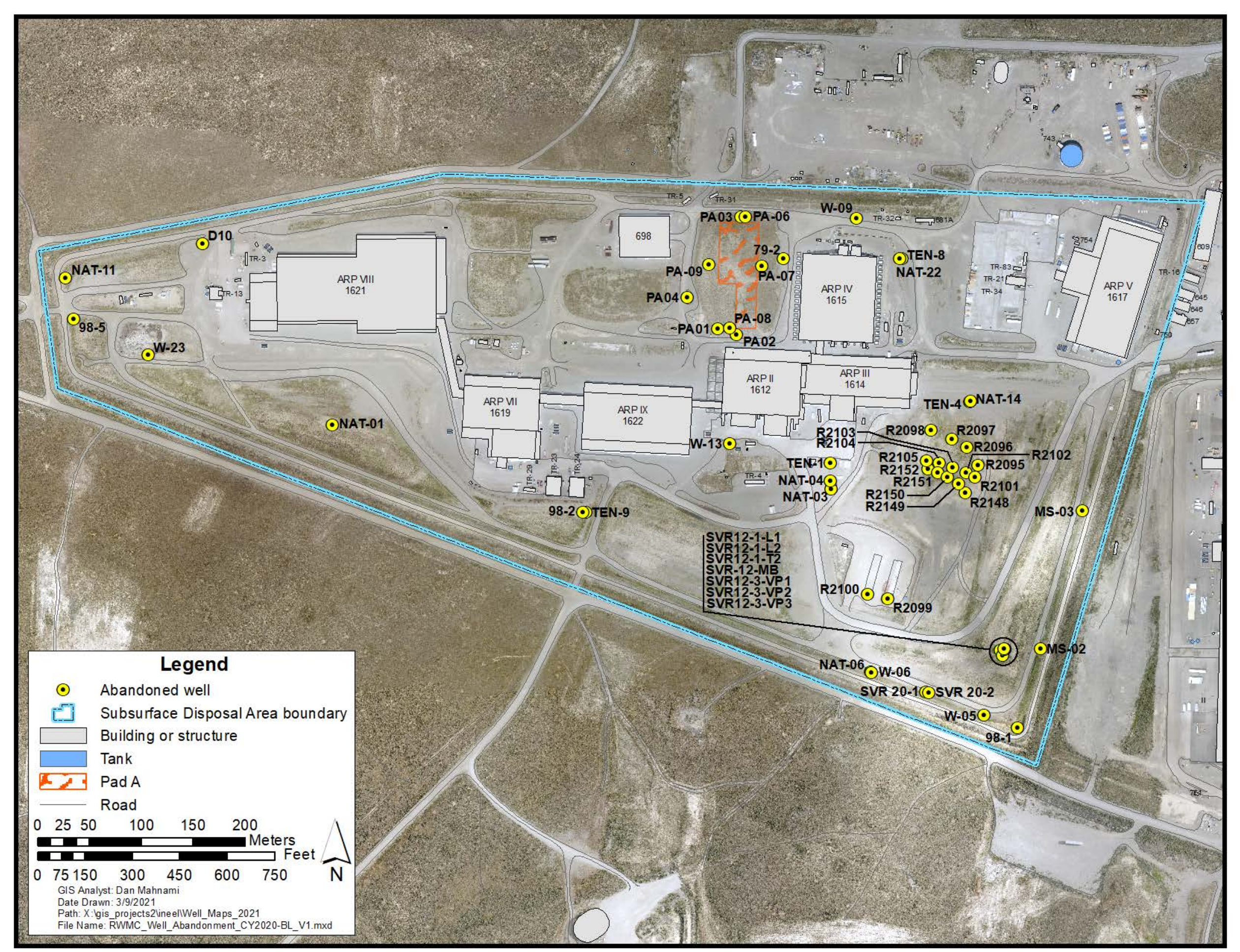




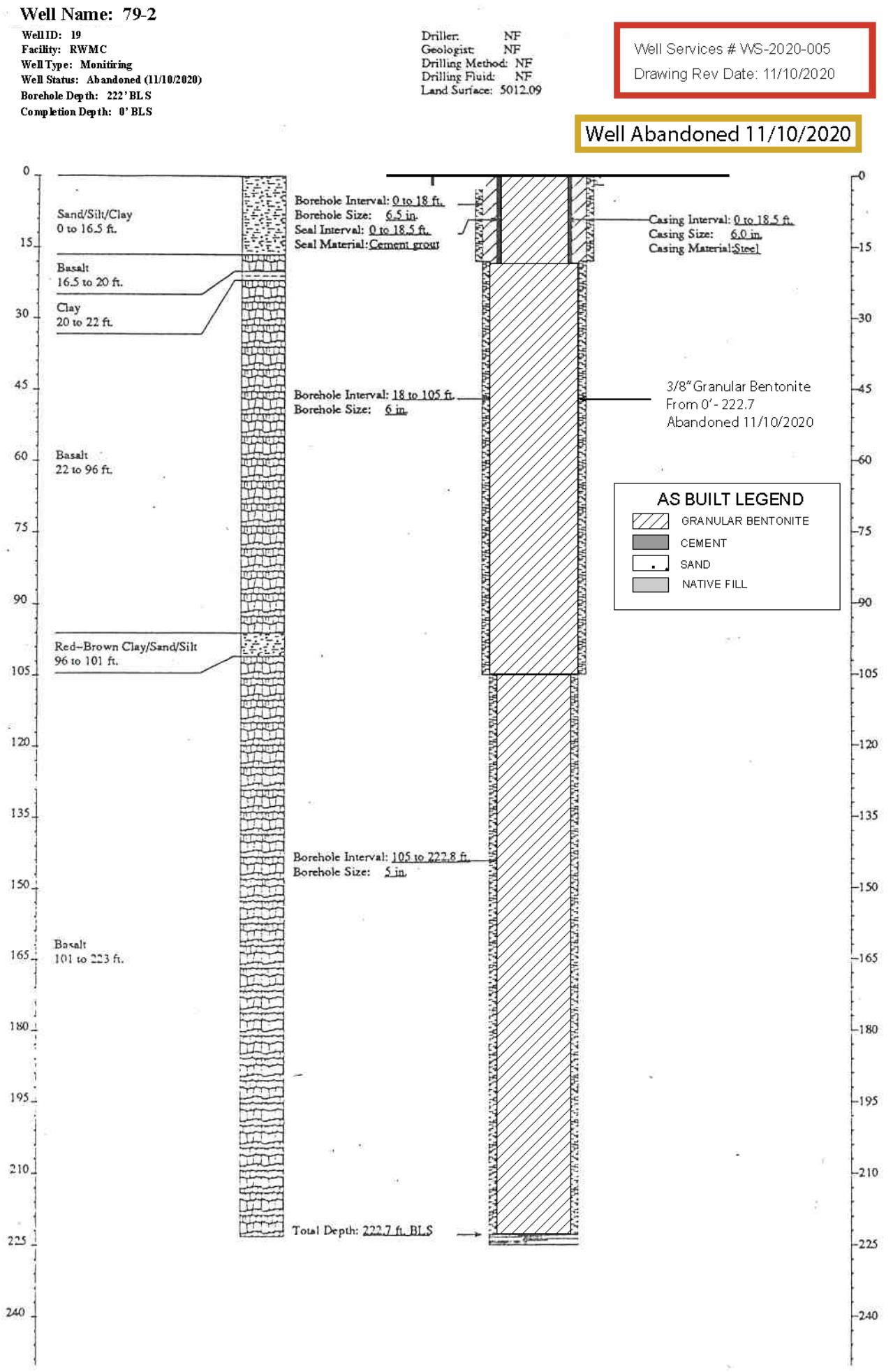

Figure B-2. Construction diagram of abandoned well 79-2. 


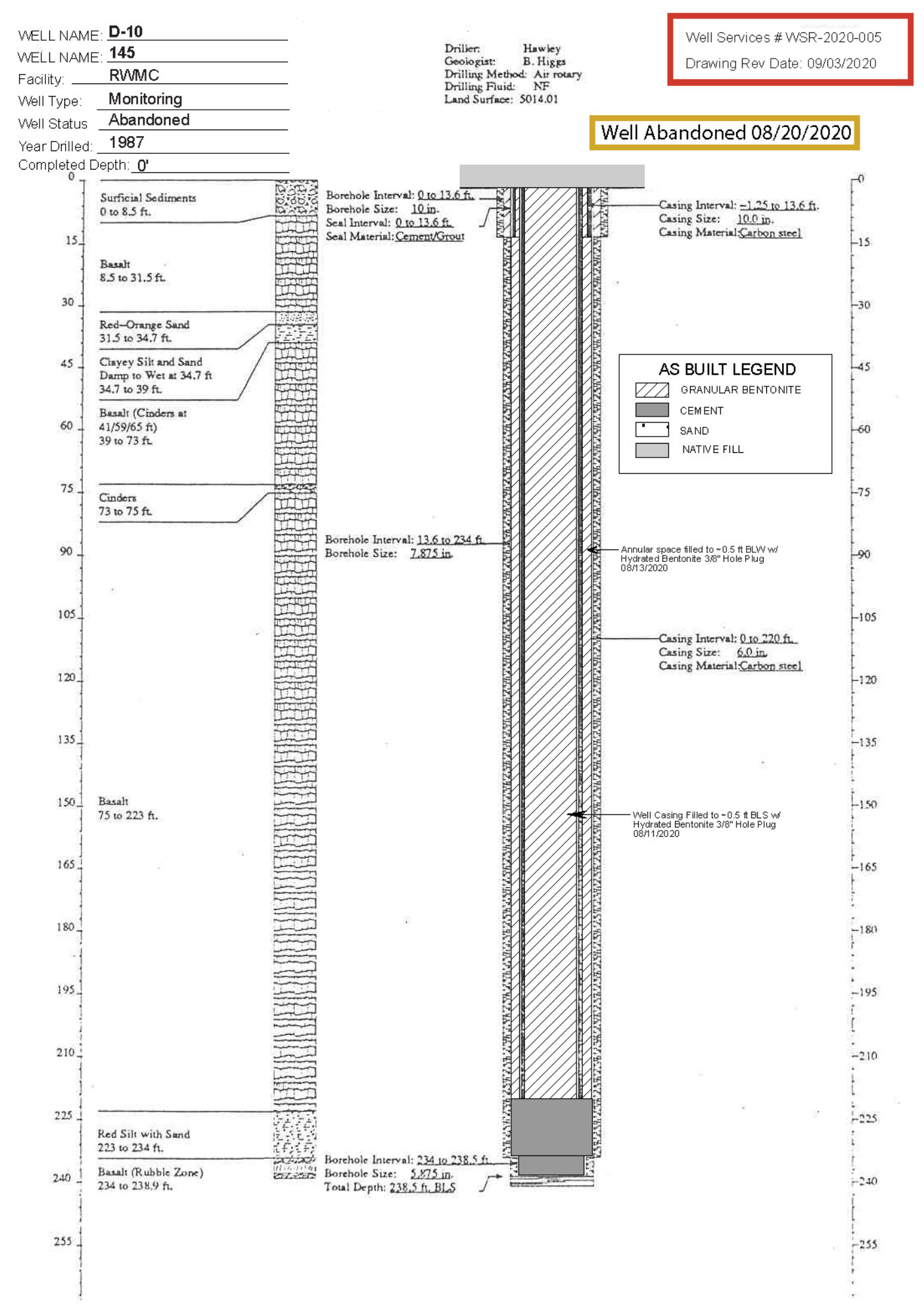

Figure B-3. Construction diagram of abandoned well D-10. 


\section{WellName: W-13}

Weill Type: RMC Scientific Instrumentation Well Status: Abandoned (Aug. 2020) $\begin{array}{ll}\text { Year Drilled: } & 1986 \\ \text { Total Depth } & 18\end{array}$

Completion Depth: 0

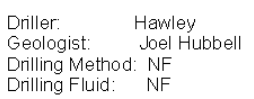

Well Services \# WS-2020-005

Drawing Rev Date: 09/16/2020

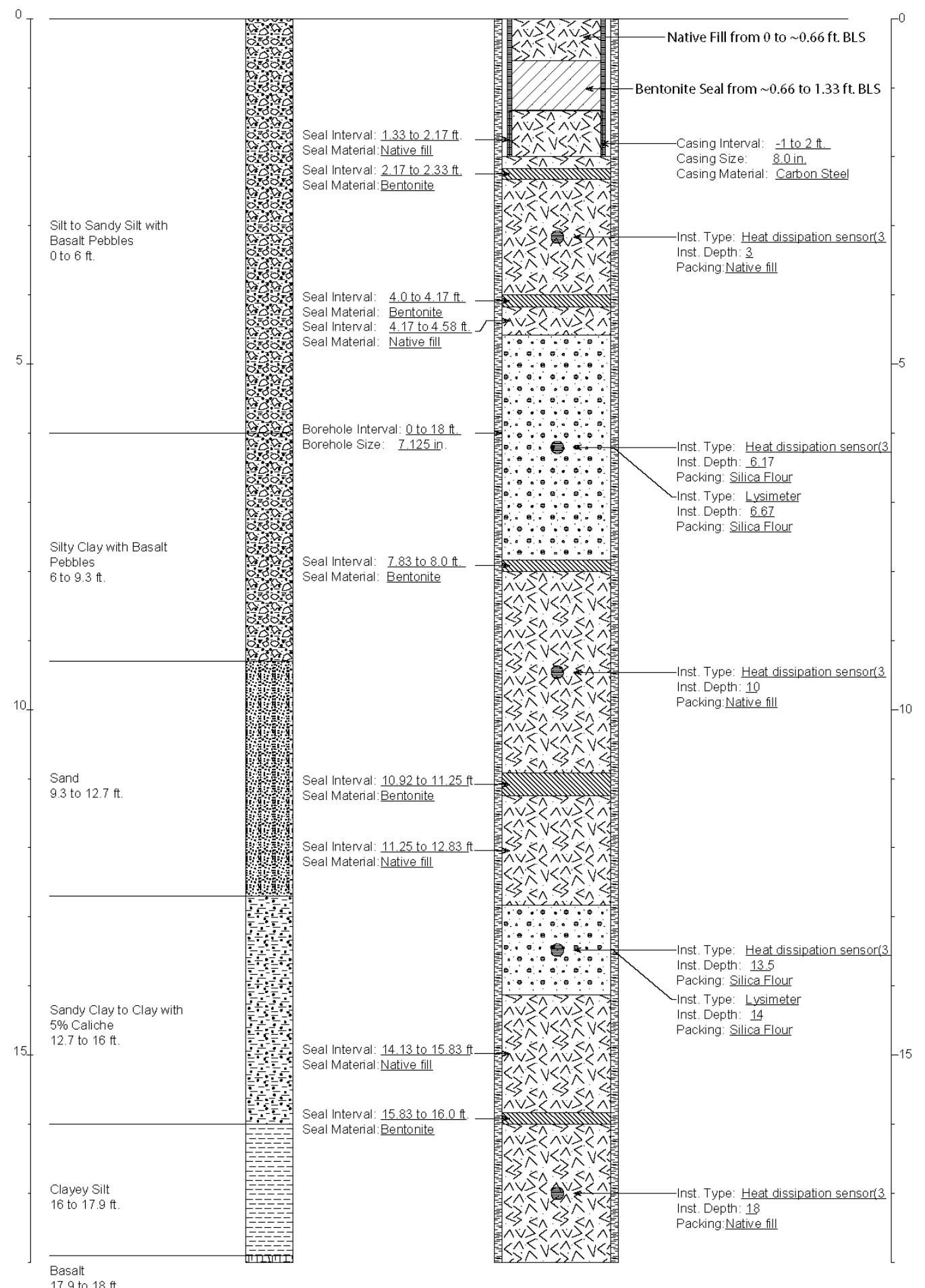

Figure B-4. Construction diagram of abandoned instrumented borehole W-13. 


\section{WellName: W-23}

Facility: RYMC

Well Status: Abandoned (Aug. 2020)

Year Drilled: 1985

Total Depth: 19.83
Completion Depth:

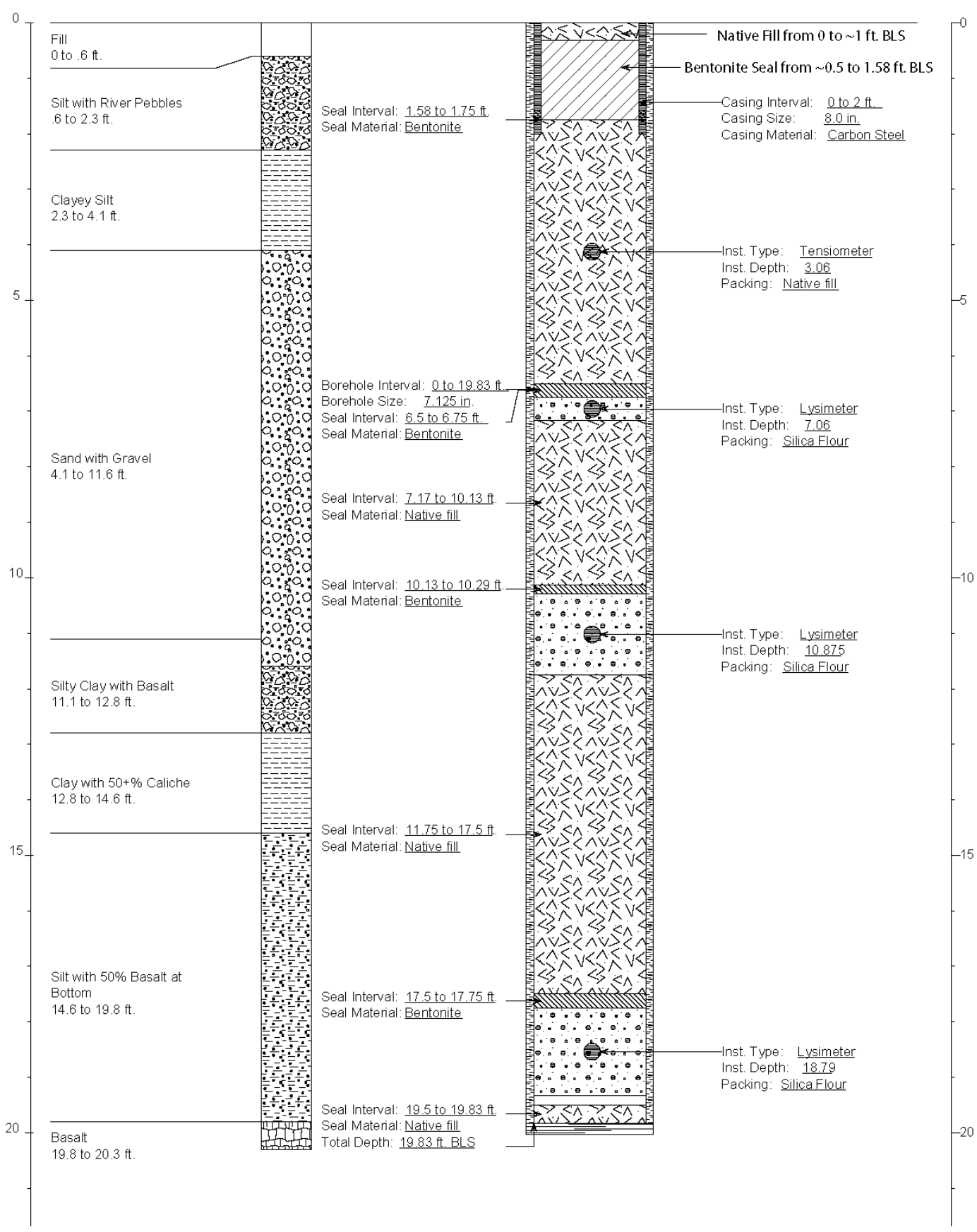

Figure B-5. Construction diagram of abandoned instrumented borehole W-23. 